\title{
Glutamate Receptor 1 Phosphorylation at Serine 831 and 845 Modulates Seizure Susceptibility and Hippocampal Hyperexcitability after Early Life Seizures
}

\author{
Sanjay N. Rakhade, ${ }^{1}$ Erin F. Fitzgerald, ${ }^{1}$ Peter M. Klein, ${ }^{1}$ Chengwen Zhou, ${ }^{1}$ Hongyu Sun, ${ }^{1}$ Richard L. Huganir,${ }^{3}$ \\ and Frances E. Jensen ${ }^{1,2}$ \\ ${ }^{1}$ Department of Neurology, Children's Hospital and Harvard Medical School, and 2Program in Neuroscience, Harvard Medical School, Boston, \\ Massachusetts 02115, and ${ }^{3}$ Solomon H. Snyder Department of Neuroscience, Johns Hopkins University School of Medicine, Baltimore, Maryland 21205
}

\begin{abstract}
Neonatal seizures can lead to later life epilepsy and neurobehavioral deficits, and there are no treatments to prevent these sequelae. We showed previously that hypoxia-induced seizures in a neonatal rat model induce rapid phosphorylation of serine-831 (S831) and Serine 845 (S845) sites of the AMPA receptor GluR1 subunit and later neuronal hyperexcitability and epilepsy, suggesting that seizure-induced posttranslational modifications may represent a novel therapeutic target. To unambiguously assess the contribution of these sites, we examined seizure susceptibility in wild-type mice versus transgenic knock-in mice with deficits in GluR1 S831 and S845 phosphorylation [GluR1 double-phosphomutant (GluR1 DPM) mice]. Phosphorylation of the GluR1 S831 and S845 sites was significantly increased in the hippocampus and cortex after a single episode of pentyleneterazol-induced seizures in postnatal day 7 (P7) wild-type mouse pups and that transgenic knock-in mice have a higher threshold and longer latencies to seizures. Like the rat, hypoxic seizures in P9 C57BL/6N wild-type mice resulted in transient increases in GluR1 S831 and GluR1 S845 phosphorylation in cortex and were associated with enhanced seizure susceptibility to later-life kainic-acid-induced seizures. In contrast, later-life seizure susceptibility after hypoxiainduced seizures was attenuated in GluR1 DPM mice, supporting a role for posttranslational modifications in seizure-induced network excitability. Finally, human hippocampal samples from neonatal seizure autopsy cases also showed an increase in GluR1 S831 and S845, supporting the validation of this potential therapeutic target in human tissue.
\end{abstract}

\section{Introduction}

Epilepsy affects $\sim 65$ million people worldwide and seizure susceptibility is high in the neonatal period (Hauser et al., 1993), with an estimated incidence of two to five per thousand live births (Ronen et al., 2007). Early life seizures can lead to development of epilepsy and other neurological deficits in adult life (Ben-Ari and Holmes, 2006; Ronen et al., 2007). To date, there are only seizuresuppressing drugs but no cure to modify epileptogenesis or the associated psychiatric or cognitive comorbidities that develop in later life (Jensen, 2011). Understanding the molecular mechanisms involved in the effect of early life seizures on synaptic func-

\footnotetext{
Received Nov. 22, 2011; revised July 23, 2012; accepted Sept. 25, 2012.

Author contributions: S.N.R., C.Z., H.S., and F.E.J. designed research; S.N.R., E.F.F., P.M.K., C.Z., and H.S. performed research; R.L.H. contributed unpublished reagents/analytic tools; S.N.R., E.F.F., P.M.K., C.Z., H.S., R.L.H., and F.E.J. analyzed data; S.N.R., R.L.H., and F.E.J. wrote the paper.

This work was supported by National Institutes of Health Grants NS 031718 and DP1 0D003347 (F.E.J.) (from the Office of the Director) and Intellectual Developmental Disabilities Research Center Grant P30 HD18655 (National Institute of (hild Health and Human Development). Human tissue was obtained from the National Institute of Child Health and Human Development Brain and Tissue Bank for Developmental Disorders at the University of Maryland (Reference N01-HD-09-0011). We thank Michelle Johnson for assistance with animal handling and immunoblot experiments. We thank members of the Jensen laboratory for valuable discussion. C.Z. and H.S. contributed to electrophysiology experiments.

The authors declare that they have no competing financial interests.

Correspondence should be addressed to Dr. Frances E. Jensen, CLS 14073, 300 Longwood Avenue, Boston, MA 02115. E-mail: Frances.Jensen@childrens.harvard.edu.

DOI:10.1523/JNEUROSCI.6121-11.2012

Copyright $\odot 2012$ the authors $\quad 0270-6474 / 12 / 3217800-13 \$ 15.00 / 0$
}

tion, including epileptogenesis, will be critical in developing appropriate therapies targeted at preventing these long-term sequelae.

We have demonstrated recently an early and reversible enhancement of AMPA receptor (AMPAR) expression and function in hippocampal and cortical neurons after seizures in young rats (Rakhade et al., 2008; Zhou et al., 2011). Similar to the clinical disease, experimental early life seizures in rodents result in long-term epilepsy and cognitive sequelae (Chen et al., 1999; Sogawa et al., 2001; Jensen, 2011; Zhou et al., 2011), and even a single neonatal seizure may permanently alter glutamatergic synapses (Cornejo et al., 2007; Zhou et al., 2011). Furthermore, in this early neonatal period of development, AMPARs are essentially $\mathrm{Ca}^{2+}$ permeable attributable to their subunit composition (Sanchez et al., 2001; Kumar et al., 2002). Importantly, seizures in the immature rat lead to transient increases in phosphorylation at the AMPAR GluR1 subunit serine 831 (S831) and S845 sites, and this is associated with increases in AMPAR-mediated synaptic currents(Rakhade et al., 2008).

Dynamic activity-dependent alterations and trafficking of AMPARs to and from the synaptic surface are thought to underlie changes in synaptic strength (Shepherd and Huganir, 2007; Heine et al., 2008). The strength of synaptic transmission in intact neuronal networks can be regulated by AMPAR function mediated by phosphorylation of GluR1 S831 and S845 subunit sites, as is observed in long-term potentiation (LTP) (Barria et al., 1997; 
Lee et al., 2000; Lee et al., 2003). Indeed, in a rat model of early life seizures, alterations in GluR phosphorylation are associated with impaired LTP, partly attributable to a reduction in available NMDA-only "silent synapses" as a result of insertion of GluR1 subunit at the synapse (Zhou et al., 2011) and autism-like behavioral abnormalities (Talos et al., 2012). Furthermore, systemic administration of an AMPAR antagonist within the first $48 \mathrm{~h}$ after seizure suppressed these early changes as well as prevented later life impairments in LTP and increased seizure susceptibility (Rakhade et al., 2008; Zhou et al., 2011).

To unambiguously identify a role for AMPAR phosphorylation in promoting long-term neurological deficits after early life seizures, we studied the effects of neonatal seizures in GluR1 double-phosphomutant transgenic knock-in mice with mutations introduced at GluR1 S831 and S845 [hereafter referred to as GluR1 double-phosphomutant (GluR1 DPM) mice] (Lee et al., 2003). Previous reports have demonstrated that the GluR1 DPM mice have impaired spatial memory, deficits in reinforcement of repetitive learning, emotion-enhanced learning, and reinforcement of addiction to cocaine and morphine (Hu et al., 2007; Billa et al., 2009).

In this study, we compared the GluR1 DPM and wild-type (WT) mice to determine whether the lack of ability to phosphorylate these sites subacutely altered seizure susceptibility to pentylenetatrazol (PTZ) and hypoxia. We assessed seizure-induced increases in hippocampal neuronal excitability and AMPARmediated EPSCs, in addition to later life seizure susceptibility. Finally, we examined phosphorylation of S831 and S845 in postmortem human brain tissue from patients with neonatal seizures compared with controls. These studies were performed to provide evidence for seizure-induced phosphorylation of GluR1 as a potential target for antiepileptogenic therapy.

\section{Materials and Methods}

Subjects

Mice with serine to alanine mutations of GluR1 S831 and S845 phosphorylation sites (GluR1 DPM mice) were generated as described previously (Lee et al., 2003). Mutation sites were verified using phosphorylation-selective antibodies against GluR1. WT and GluR1 DPM (homozygous) mice with C57BL/6N hybrid genetic background were used for all experiments. All experiments were performed on mice aged postnatal day 5 (P5) to P40, which had been weaned at P21 and maintained on a $12 \mathrm{~h}$ light/dark schedule. In experiments in which no mutant mice were used for comparing ontogenic expression of neurotransmitter receptors, WT C57BL6/N mice subjects were obtained from commercial vendors (Charles River Laboratories). All of the electrophysiological experiments comparing WT with GluR1 DPM mice were performed blinded to the genotype of the mice being recorded. All procedures related to animal care and treatments conformed to the guidelines and policies and were approved by the Animal Care and Use Committee of Children's Hospital Boston.

\section{Seizure induction}

The critical period of developmental plasticity with an imbalance between cortical excitation and inhibition has been described previously as a factor in determining the onset of neonatal seizures (Silverstein and Jensen, 2007; Rakhade and Jensen, 2009). This critical period is defined by the expression of neurotransmitter receptors and ion transporters in the neocortex. The transition between the expression pattern of these receptors and transporters from an immature to a more mature pattern has been observed to be ontogenitically conserved across rodent species. Because much of the previous work on hypoxic seizures (HS) has been conducted in a rat model, a goal of this study was to develop mouse models in an analogous age window. To establish the critical period of this transition and the time window for the initiation of early life seizures in the C57BL/6 mouse, at P5-P10, we studied the expression pattern of the ionotropic glutamate receptors for both the AMPA and NMDA sub- types, including GluR1, GluR2, NR1, NR2A, and NR2B. We also studied the expression of the GABA subtype receptors $\mathrm{GABA}_{\mathrm{A}} \alpha 1$ and $\mathrm{GABA}_{\mathrm{A}} \alpha 4$, as well as the chloride ion transporters NKCC1 and KCC2 (Fig. 1). GluR1 expression within this time window was observed to be highest at P9 $(154 \pm 24 \%, n=8, p<0.05)$, with a decrease in expression with increasing age. GluR2 receptor expression continued to increase with age from $\mathrm{P} 5$ to P10. GluR2 receptor expression levels at P5-P7 were significantly lower $(48 \pm 21 \%, n=5, p<0.05)$ compared with the levels at P10. Similarly, NR2A receptor expression levels at P5 were significantly lower $(49 \pm 6 \%, n=5, p<0.05)$ compared with the levels at P10 and increased gradually in the intervening time window. The expression levels of NR2B receptor subunit at P5 $(105 \pm 12 \%, n=5)$ were not significantly different from the expression levels at P10. The expression levels of KCC2 at P5 were significantly lower $(21 \pm 8 \%, n=5, p<0.05)$ compared with the levels at P10. Similarly, the expression levels of $\mathrm{GABA}_{\mathrm{A}} \alpha 1$ at P5 were significantly lower $(10 \pm 5 \%, n=5, p<0.05)$ compared with the levels of P10. The expression levels of $\mathrm{GABA}_{\mathrm{A}} \alpha 4$ subunit were peaking at P9 $(136 \pm 9 \%, n=5, p<0.05)$ compared with the levels of P10 and decreased significantly later in life. The neonatal age window between P7 and $\mathrm{P} 9$ displayed the maximal transition in these receptors and transporters. Based on the neurotransmitter and ion transporter expression patterns, we chose the time window between P7 and P9 for seizure induction, given the similarities to the P10 Long-Evans rat developmental expression.

\section{Chemoconvulsant-induced seizures in immature mice}

For chemoconvulsant seizures, PTZ ( $50 \mathrm{mg} / \mathrm{kg}$, i.p.) was administered to P7 mice. P7 was chosen because data showed that administration of PTZ leads to induction of spike and wave epileptic activity in the mice pups (Velisek et al., 1992). The severity of convulsive responses was videotaped and then classified by a blinded investigator according to the Racine scale: 0 , no response; 1 , facial jerks, pawing; 2 , nodding, wet-dog shakes, myoclonic jerks; 3 , forelimb clonus; 4 , loss of posture, hindlimb tonicclonic movements; 5 status epilepticus and death.

\section{Hypoxia-induced seizures in immature mice}

For seizure induction by hypoxia, pilot data showed that optimal seizures in C57BL/6 were obtained at P9. HS were induced by graded global hypoxia administered for $40 \mathrm{~min}$. Briefly, oxygen concentration was maintained alternately at $9 \%$ for $5 \mathrm{~min}$ and a reduced concentration $(6$, $5.5,5$, and $5 \%$ sequentially) for 5 min periods for a total duration of 40 min before termination of hypoxia. Seizures were recorded with videomonitoring equipment, and severity and latency were measured. Littermate controls were kept at room air. For all groups, normothermic body temperature was maintained at $32-34^{\circ} \mathrm{C}$ on a circulating water heating pad. For both sets of seizure-induction methods, the entire mouse litter was returned to their dams within $1 \mathrm{~h}$ of initiating the experiment. Difference in seizure induction in the different groups studied was assessed using $\chi^{2}$ test.

\section{Assessment of later life seizure susceptibility}

Mouse pups exposed to early life seizures were allowed to survive into adulthood, and latency to chemoconvulsant-induced seizures [kainic acid (KA), $35 \mathrm{mg} / \mathrm{kg}$, i.p.] was measured at P40. Mouse pups were divided into four groups; WT naive mice without seizures, WT mice that had experienced HS at P9, GluR1 DPM naive mice with no seizures, and GluR1 DPM mice that had experienced HS at P9. KA seizures have been documented extensively and reported previously, the severity of the KA seizures was classified according to the Racine scale described above. Video recordings of the seizures were performed to measure the latency to the first seizure in the appropriate severity scale. Time to the first behavior was calculated to determine the latency to seizure onset, and data were normalized within each litter, with the time to latency to first behavioral seizures in the WT controls without seizures at P9 as a normalizing control.

\section{Hippocampal slice preparation and electrophysiology}

Hippocampal slices were prepared, and whole-cell recordings were obtained from acute hippocampal slices prepared from mouse pups as described in detail previously (Sanchez et al., 2005a; Zhou et al., 2011). Hippocampal slices from GluR1 DPM and WT mice were used for electrophysiological 
recordings at $24 \mathrm{~h}$ after the PTZ-induced seizures. Mouse pups were decapitated at $24 \mathrm{~h}$ after PTZtreatment-induced neonatal seizures with procedures in accordance with guidelines set by the institutional animal care and use committee, and age-matched mouse pups were used as controls for both GluR1 WT and GluR1 DPM mice. WT littermate mice that had not been exposed to PTZ were used as baseline controls. We focused on the subacute time period after induction of PTZ seizures for determining changes in hippocampal hyperexcitability, allowing for the washout of residual PTZ from the brain before ex vivo measurements of hippocampal excitability (Ramzan and Levy, 1985). Mouse brains were rapidly dissected from the skull and placed for sectioning in ice-cooled cutting solution bubbled with 95\% $\mathrm{O}_{2} / 5 \% \mathrm{CO}_{2}$ at $4^{\circ} \mathrm{C}$. Coronal hippocampal slices (300 $\mu \mathrm{m}$ thickness) were sectioned from the middle third of hippocampus with a vibratome (WPI) in cutting solution containing the following (in mM): 210 sucrose, $2.5 \mathrm{KCl}, 1.02 \mathrm{NaH}_{2} \mathrm{PO}_{4}$, $0.5 \mathrm{CaCl}_{2}, 10 \mathrm{MgSO}_{4}, 26.19 \mathrm{NaHCO} 3$, and 10 D-glucose, $\mathrm{pH}$ 7.4. Slices were incubated in oxygenated artificial CSF (ACSF; composition as described previously) (Rakhade et al., 2008; Zhou et al., 2011) and remained at $32^{\circ} \mathrm{C}$ for $30 \mathrm{~min}$. Slices were maintained at room temperature for at least $1 \mathrm{~h}$ before electrophysiological recordings were performed at $32^{\circ} \mathrm{C}$.

Whole-cell patch-clamp recordings were made from CA1 pyramidal neurons in hippocampal brain slices using infrared/differential interference contrast microscopy as described previously (Zhou et al., 2011). All recordings were performed after a $1 \mathrm{~h}$ incubation period, allowing for washout of any systemically administered drugs (Kapus et al., 2000). The patch-pipette internal solution contained $110 \mathrm{~mm}$ Cs-methanesulfonate, 10 $\mathrm{mm}$ tetraethylammonium-Cl, $4 \mathrm{~mm} \mathrm{NaCl}, 2$ mм $\mathrm{MgCl}_{2}, 10$ mм EGTA, 10 mм HEPES, 4 mм ATP-Mg, and $0.3 \mathrm{~mm}$ GTP, pH 7.25, with QX-314 [(N-2,6 dimethyl phenylcarbamoylmethyl) triethylammonium chloride] and creatine phosphokinase $(17 \mathrm{U} / \mathrm{ml})$. Filled electrodes had resistances of 2-5 M 2 . AMPARmediated EPSCs were pharmacologically isolated by blocking GABA and NMDA receptors with picrotoxin $(60 \mu \mathrm{M})$ and DL-AP-5 (100 $\mu \mathrm{M})$, respectively. TTX $(1 \mu \mathrm{M})$ was added to the ACSF to record miniature EPSCs (mEPSCs). All recordings were performed at $32^{\circ} \mathrm{C}$. Briefly, mEPSCs were detected automatically using Clampfit 9.2 (Molecular Devices), and frequency and amplitude histograms were constructed using this program as described previously (Wyllie and Nicoll, 1994). The threshold for detection of mEPSC events was set at $5 \mathrm{pA}$. This threshold remained constant throughout the analysis of whole experiments for all recordings. All detected mEPSCs were visually checked for a monotonic rising phase and an approximately exponential decay time course.

\section{Immunoblotting}

For comparing the ontogenic expression pattern of AMPARs, GluR1 DPM mice and WT littermates were killed at P5, P6, P7, P8, P9, and P10. GluR1 DPM mice and their WT littermate controls were killed at 1, 3, 6,

B
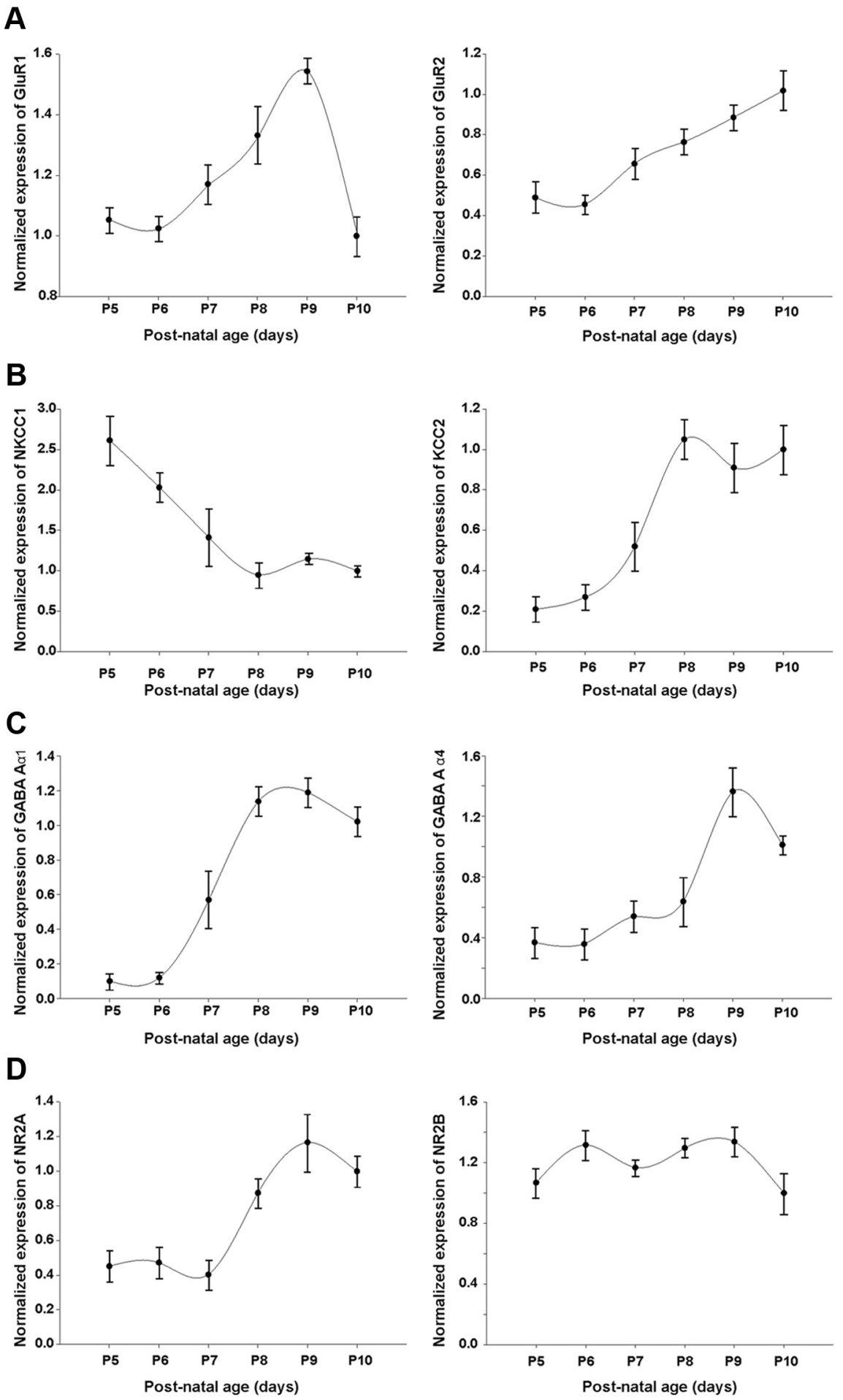

Figure 1. Developmental regulation of membrane-expressed neurotransmitter and ion transporter subunits in the cortex from C57BL/6N mice. Western blot quantification of GluR1 and GluR2 subunits $(\boldsymbol{A})$, NKCC1 and KCC2 chloride ion transporters $(\boldsymbol{B})$, $G_{A B A_{A}} \alpha 1$ and $G A B A_{A} \alpha 4$ subunits $(\boldsymbol{C})$, and NR2A and NR2B receptor subunits $(\boldsymbol{D})$ at different postnatal ages compared with P10 standard (1.0) demonstrates that the critical period between P7 and P9 in the mice has several key transitions in the expression of these subunits from an immature to a more mature profile. These may contribute to the enhanced excitability in this period of brain development in the immature mice.
12, 24, and $48 \mathrm{~h}$ after PTZ-induced seizures were induced at P7. Brain tissue was dissected out immediately, and cortical and hippocampal regions were separated under a dissecting microscope. Tissue was then rapidly frozen in ethanol and stored at $-80^{\circ} \mathrm{C}$ until used for protein extraction. A similar procedure was followed for collection of brain tissue 
Table 1. Clinical and neuropathological characteristics for tissue from human subjects

\begin{tabular}{|c|c|c|c|c|c|c|}
\hline Subject & Sex & Pathology & $\begin{array}{l}\text { Age at } \\
\text { autopsy }\end{array}$ & PMI (h) & Cause of death & Brain region \\
\hline C1 & Male & & 6 months & 17 & Myocarditis & Hippocampus \\
\hline $\mathrm{C} 2$ & Male & & $18 d$ & 7 & Unknown & Hippocampus \\
\hline C3 & Male & & $5 d$ & 5 & Congenital heart defect & Hippocampus \\
\hline S1 & Male & Perinatal asphyxia, neonatal seizures & $5 d$ & 13 & Complications of seizures & Hippocampus \\
\hline S2 & Female & Perinatal asphyxia, neonatal seizures & $30 d$ & 17 & Developmental seizure disorder & Hippocampus \\
\hline S3 & Female & HIE, neonatal seizures & $2 d$ & 3 & Anoxia, hypoxic ischemic encephalopathy & Hippocampus \\
\hline
\end{tabular}

PMI, Postmortem interval.

at 1, 12, 24, and $48 \mathrm{~h}$ after hypoxia-induced seizures at P9. Membrane protein samples from the anterior two-thirds of cortex and the entire hippocampal tissue were prepared as described previously (Wenthold et al., 1992; Talos et al., 2006). Complete Mini Protease Inhibitor Cocktail Tablet (Roche), HALT phosphatase inhibitor tablet (Sigma-Aldrich), and phosphatase inhibitor PMSF (10 mM) were added to inhibit proteases and phosphatases. Total protein concentrations were measured using Bradford protein assay (Bio-Rad), and samples were diluted for equal amounts of protein in each sample. Samples were electrophoretically separated on $7.5 \%$ Tris- $\mathrm{HCl}$ gels and transferred to polyvinylidene difluoride membranes. Blots were blocked and incubated with primary and secondary antibodies. Phosphospecific antibodies raised against GluR1 S831 (1:1000 dilution), GluR1 S845 (1:1000 dilution), and GluR2 S880 (1:1000 dilution) (Millipore Corporation) were used in immunoblotting studies. The membranes were stripped using Restore Stripping buffer (Thermo Fisher Scientific) as per the protocols of the manufacturers and reprobed with antibodies raised against GluR1 subunits (1:1000 dilution; Millipore Corporation), GluR2 (1:1000 dilution; Millipore Corporation), NR1 and NR2 (1:1000 dilution; Millipore Corporation), NKCC1 (1:500 dilution; Millipore Corporation), KCC2 (1:500 dilution; Abcam), $\mathrm{GABA}_{\mathrm{A}} \alpha 1$ and $\mathrm{GABA}_{\mathrm{A}} \alpha 4$ (1:1000 dilution; Millipore Corporation), and postsynaptic density 95 (PSD-95) (1:1000 dilution; Cell Signaling Technology) as described previously (Talos et al., 2006; Rakhade et al., 2008). Appropriate anti-mouse or anti-rabbit IgG antibodies (1: 5000 dilution; Pierce) were used, and immunodetection was effected using Super-West Femto Maximum Sensitivity Substrate reagent (Thermo Fisher Scientific). Digital images were recorded using the Fuji Image LAS 4000 (Fujifilm) chemiluminescence detection system. Densitometric analysis of the digital images was performed using Fujifilm MultiGauge image-analysis software to measure the optical signal density from each sample. The amount of phosphorylation observed was standardized to the amount of receptor subunit present in each sample.

Analysis of posttranslational modifications in human brain tissue Human parietal-occipital lobe specimens were collected from neonatal and pediatric autopsy populations. Cases ranged from $2 \mathrm{~d}$ after birth (neonatal period) to 6 months of age ( $n=6,4$ males and 2 females). Brain tissue was obtained from cases from the University of Maryland Brain and Tissue Bank for Developmental Disorders (Table 1). The samples were obtained from standard diagnostic postmortem examinations, and all procedures and experiments were conducted under guidelines approved by the Clinical Research Committee at all institutions. The causes of death are listed in Table 1. When possible, the postmortem interval was limited to $\leq 24 \mathrm{~h}$, and the postmortem interval durations are provided in Table 1.

\section{Statistical analyses}

Group data were expressed as mean \pm SEM, and $n$ is the number of mice for a given data point. Statistical significance was defined as $p<0.05$.

Analysis for Western blots. Protein bands were visualized with enhanced chemiluminescence (Pierce) using the Image Reader LAS-3000 system, and densitometric analysis was performed using Image Gauge version 3.0 software (Fujifilm) as described above. Normalized values for expression of phospho-protein/total protein (for WT and GluR1 DPM mouse brain tissue run on the same blot with multiple time points) were expressed as a percentage of the mean. Expression of neurotransmitter receptors was similarly calculated as percentage of the mean compared with expression of the receptor observed at P10. Expression of $\beta$-actin was used for normalization for equal protein loading between samples. Data across multiple time points after induction of seizures were compared with matched seizure-naive littermate control animals. One-way ANOVA followed by post hoc Tukey's test were used for multiple comparisons across time points. For the immunoblots comparing receptor phosphorylation in brain tissue from human subjects experiments, two tailed $t$ tests were used for assessing statistical significance.

Analysis for latency to seizure studies. Latency to behavioral seizures at stages 1-4 were measured in minutes for individuals within each litter. The latency to seizure induction was normalized within each litter for mice subjected to chemoconvulsant-induced seizures. Survival curves were plotted using GraphPad Prism (GraphPad Software). Statistical significance was assessed using Maltel-Cox log-rank test comparing the survival curves.

Analysis for electrophysiology recordings. Statistical significance for differences in the distribution of the mEPSCs for the GluR1 DPM and WT mice was assessed using one-way ANOVA test, $t$ test, and KolmogorovSmirnov test as specified in Results.

\section{Results}

\section{PTZ-induced seizures in immature WT mice result in} increased phosphorylation of neuronal GluR1 S831 and S845 We hypothesized that the increase in phosphorylation of GluR1 receptor subunit may be a pathological response shared in multiple models of early life seizures and may play a critical role in epileptogenesis, promoting increased hyperexcitability and synaptic potentiation. Previous studies implicating a role for AMPARs in mediating early life seizures used a model using P10 Long-Evans rat (Silverstein and Jensen, 2007; Rakhade et al., 2008; Rakhade and Jensen, 2009; Zhou et al., 2011). Because the GluR DPM mouse is developed on a background strain of $\mathrm{C} 57 \mathrm{BL} / 6 \mathrm{~N}$, we determined that the analogous age window in the C57BL/6N mouse was P7-P9, based on the developmental expression pattern of neurotransmitter receptors and ion transporters (Fig. 1).

In P7-P9 WT mice, we next examined the effect of seizures induced by the chemoconvulsant PTZ on GluR S831 and Glur1 S845 phosphorylation state in the cortex and hippocampus. Systemic injections of PTZ (50 mg/kg, i.p.) caused spike and wave discharges (Velisek et al., 1992), and these behavioral seizures were scored using the Racine seizure severity scale. In cortex, GluR1 S831 phosphorylation increased as early as $1 \mathrm{~h}$ compared with naive littermate controls, and this increase was maximal at $3 \mathrm{~h}$ after Racine stage IV PTZ-induced seizures ( $152 \pm 19 \%, n=7, p<0.01)$ before returning to baseline at $24 \mathrm{~h}$ (Fig. 2A). Similarly, GluR1 S845 phosphorylation in cortex increased by $1 \mathrm{~h}$ after PTZ-induced seizures and peaked $3 \mathrm{~h}$ after seizures $(147 \pm 16 \%, n=7, p<0.01)$, before returning to baseline at $24 \mathrm{~h}$ (Fig. $2 B$ ). Similar to neocortex, hippocampal tissue showed maximal increase in phosphorylation at $1 \mathrm{~h}$ after PTZ seizures for both GluR1 S831 $(159 \pm 23 \%, n=6, p<0.05)$ (Fig. $2 C$ ) and GluR1 S845 (302 $\pm 83 \%, n=6, p<0.05)$ (Fig. $2 D$ ). Together, these data suggest that seizure-induced increases in phos- 
A

Cortex
Wild-type + PTZ Szs

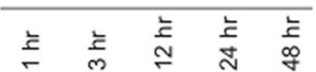
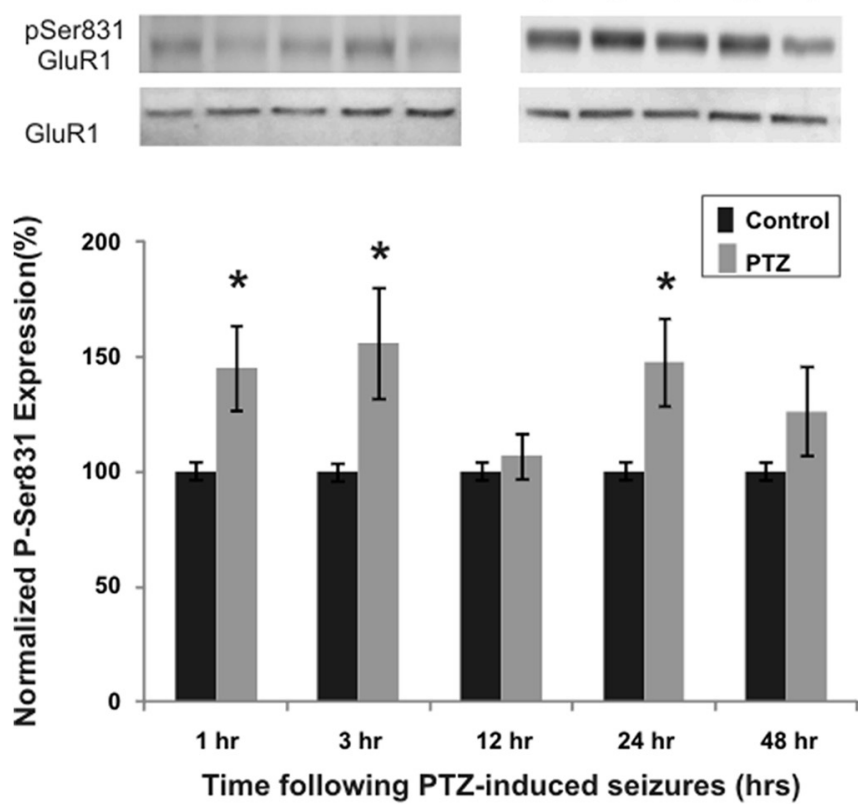

B Wild-type - Control Wild-type + PTZ Szs
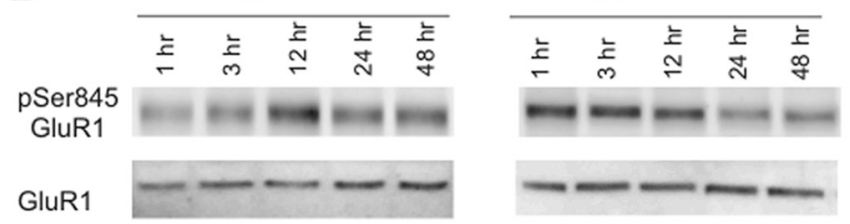

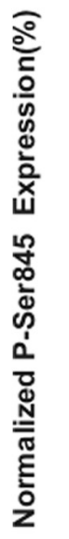

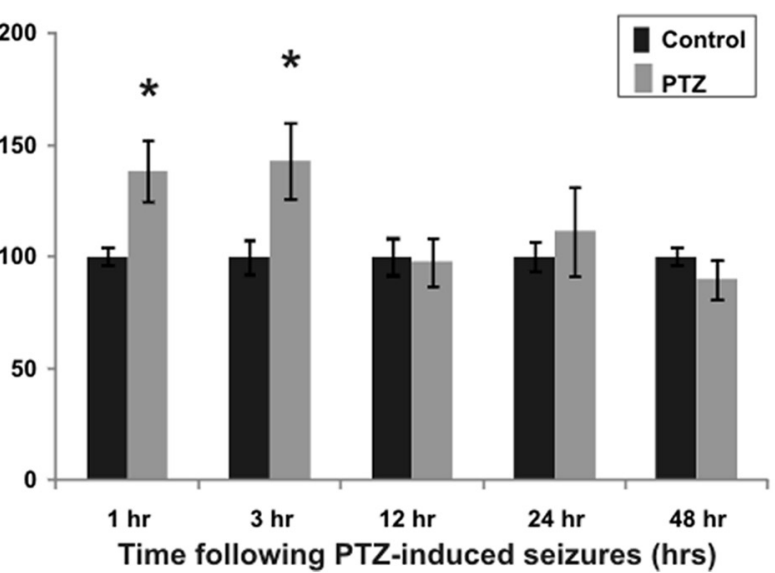

C

Hippocampus

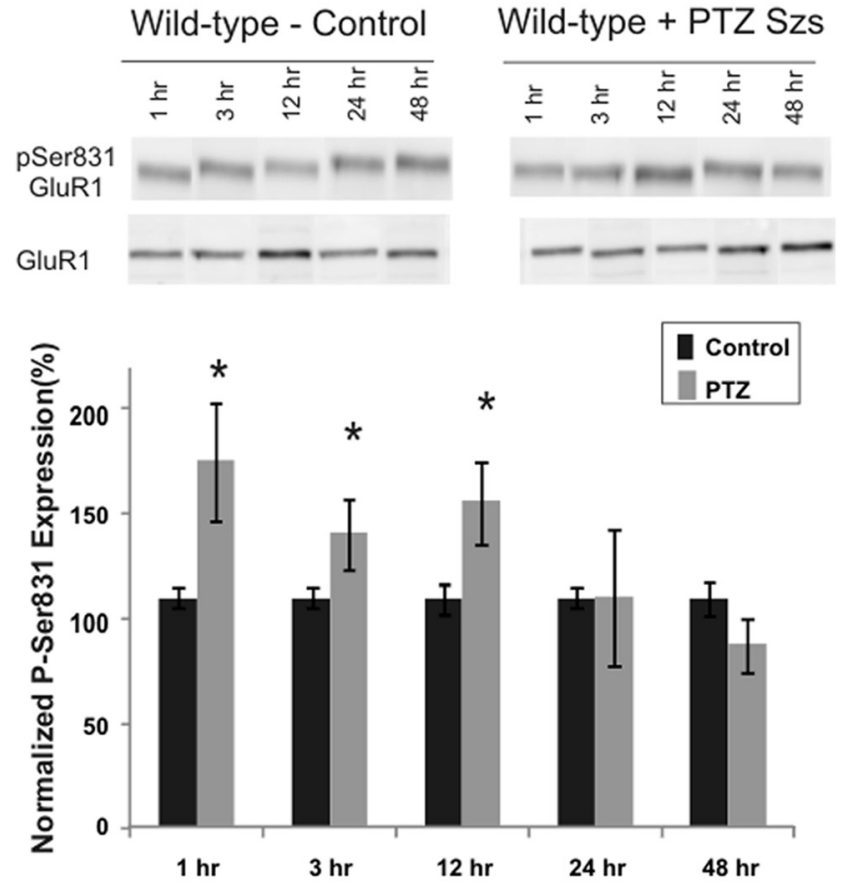

Time following PTZ-induced seizures (hrs)

D Wild-type - Control Wild-type + PTZ Szs
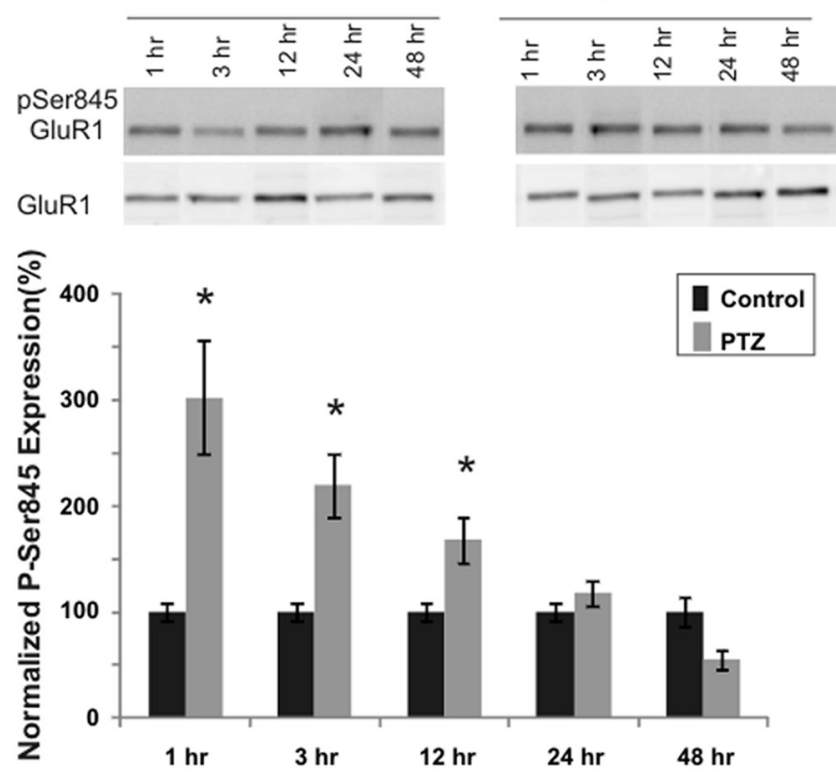

Time following PTZ-induced seizures(hrs)

Figure 2. Increase in phosphorylation of GluR1 S831/5845 after PTZ-induced neonatal seizures in C57BL/6N strain of mice. Immunoblots showing significant increase in phosphorylation of GluR1 S831 ( $\boldsymbol{A})$ and GluR1 $5845(\boldsymbol{B})$ at 1 and $3 \mathrm{~h}$ at P7 in WT mice after PTZ-induced seizures (PTZ administered at $50 \mathrm{mg} / \mathrm{kg}$, i.p.). Densitometry analysis and relative quantitation of phosphorylation of GluR1 subunit revealed the maximal increase at $3 \mathrm{~h}$ after PTZ seizures for both GluR1 $5831(152 \pm 19 \%, n=7, p<0.01)$ and GluR1 $5845(147 \pm 16 \%, n=7, p<0.01)$ in the cortex compared with non-seizing controls. Similarly, immunoblotting performed with hippocampal tissue from mice subjected to PTZ seizures $(\boldsymbol{C}, \boldsymbol{D})$ showed maximal increase in phosphorylation of GluR1 5831 at $1 \mathrm{~h}$ after PTZ seizures $(159 \pm 23 \%, n=6, p<0.05)$. GluR1 5845 phosphorylation in the hippocampal tissue was maximal at $1 \mathrm{~h}(302 \pm 83 \%, n=6, p<0.05)$ compared with littermate controls not experiencing seizures. Error bars indicate SEM. ${ }^{*} p<0.05$. 
A

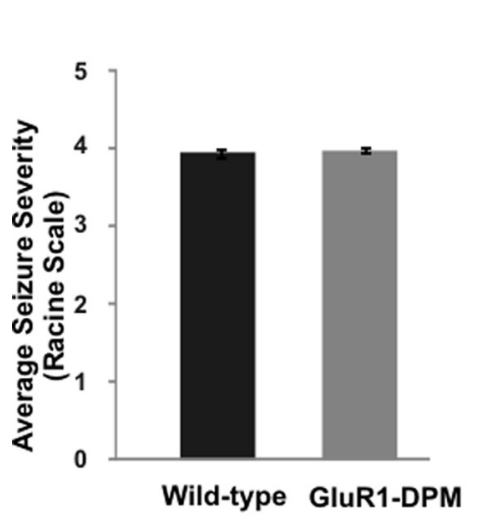

B

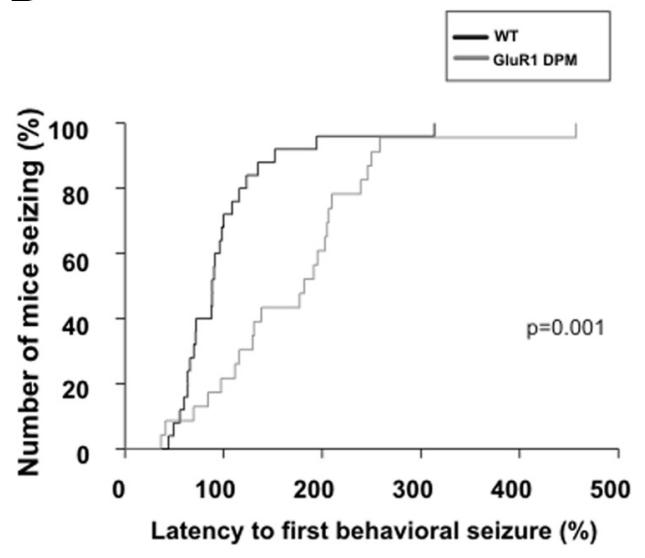

C

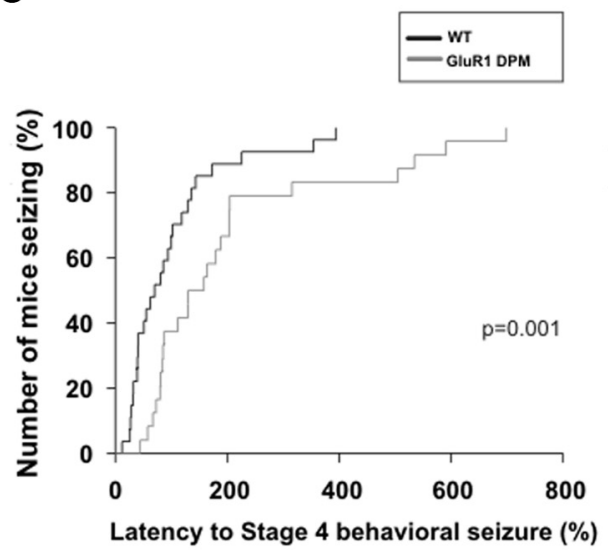

D

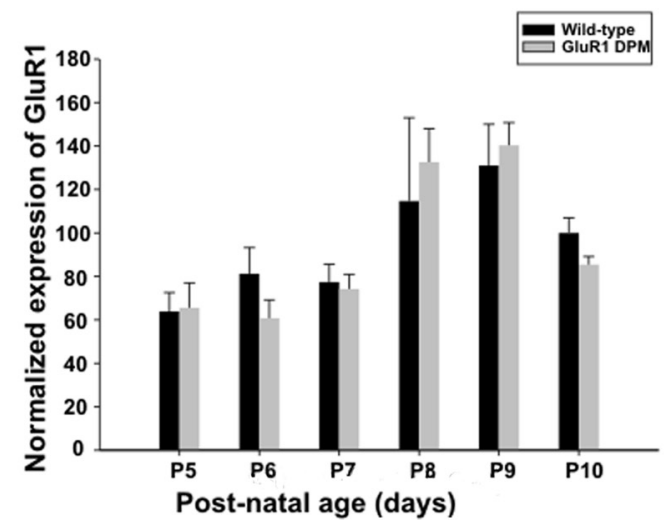

E

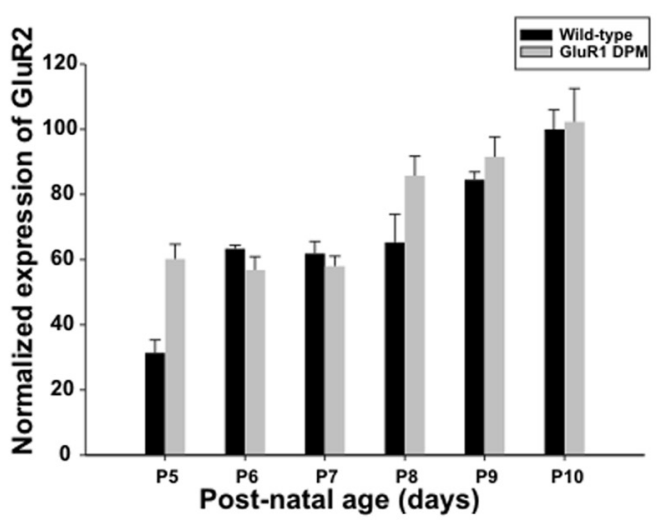

Figure 3. GluR1 DPM mice and WT mice display equal severity of seizures after PTZ administration, but latency to seizures is increased in GluR1 DPM mice. A, GluR1 DPM and WT mice were observed for $3 \mathrm{~h}$ after administration of PTZ (50 mg/kg, i.p.) to study the appearance and progression of epileptiform seizure activity. Both genotypes showed behavioral progression of seizures in accordance with Racine seizure scale of severity. GluR1 DPM mice averaged $4.05 \pm 0.12 \mathrm{~min}(n=22)$; this level was not significantly different from average seizure stage in WT controls $(3.96 \pm$ $0.17, n=23) . B$, The latency to first behavioral seizure (stage 1), after administration of PTZ ( $50 \mathrm{mg} / \mathrm{kg}, \mathrm{i} . \mathrm{p}$.), was increased in the GluR1 DPM mice (median time of $188 \pm 18 \%, n=23, p<0.001$ ) compared with littermate WT controls (median time of $100 \pm 12 \%, n=22$ ). Progressive curves depicting the onset of stage 1 behavioral seizures show the differing latencies in the GluR1 DPM $(-/-)$ and WT mice. C, Similarly latency to onset of hindlimb clonus (stage 4 seizures) was also significantly increased (median time of $204 \pm 23 \%, n=22, p<0.001$ ) compared with littermate WT controls (median time of $100 \pm 17 \%, n=23$ ). Progressive curves depicting latency to stage 4 seizures are shown. We studied the baseline expression of GluR1 and GluR2 subtypes of AMPA glutamate receptors in the cortex of the WT and GluR1 DPM mice to rule out any compensatory changes. Our data suggest a lack of any significant change in expression of Glur1 (D) and GluR2 (E) in the synaptic membrane preparation obtained from cortical samples from GluR1 DPM and WT mice between the ages of P5 and P10 evaluated using Western blot.

phorylated GluR1 S831 and S845 in WT mice were consistent with increased phosphorylation observed in Long-Evans rats after seizure (Rakhade et al., 2008).

\section{GluR1 DPM mice show delayed latency to} PTZ-induced seizures

We next evaluated the effects of seizures in the P7 GluR1 DPM transgenic mouse model. PTZ-induced seizures in the GluR1 DPM mice reached the same final level of severity $(4.05 \pm 0.12)$ compared with WT mice (3.96 \pm 0.17$)$ (Fig. 3A). However, the latency to first behavioral seizure (stage 1 ) after administration of PTZ (50 mg/kg, i.p.) was increased in the GluR1 DPM mice (median of $188 \pm 18 \%, n=23, p<0.001)$ compared with littermate WT controls (median of $100 \pm 12 \%, n=22$ ) (Fig. 3B). Similarly, latency to onset of hindlimb clonus (stage 4 seizures) was also significantly increased (median of 204, $n=22, p<0.001$ ) compared with littermate WT controls $(100 \pm 17 \%, n=23)$ (Fig. 3C). These data suggest that the lack of phosphorylation at the GluR1 S831 and S845 sites decreases seizure susceptibility but does not render these mice incapable of sustaining a PTZ-induced seizure.
To determine whether the alterations observed in seizure latency reflected alterations in baseline expression of AMPARs in the GluR1 DPM mice, we studied the expression of membrane GluR1 and GluR2 in the cortex of GluR1 DPM and age-matched WT littermates. At P7, the expression of the GluR1 was not different in the GluR1 DPM mice (74.6 \pm 8\% normalized to expression at $\mathrm{P} 10, n=6)$ compared with WT mice $(81 \pm 6 \%$ normalized to expression at P10, $n=6)$. Similarly, the expression of the GluR2 receptors at P7 in the GluR1 DPM mice ( $59 \pm 6 \%$ normalized to expression at P10, $n=6$ ) was unchanged compared with WT controls $(63 \pm 7 \%$ normalized to expression at $\mathrm{P} 10, n=6)$. Overall, comparison of the expression of GluR1 and GluR2 subtype of receptors from P5 to P10 using Western blots did not show a significant difference in their expression between the WT and GluR1 DPM mice (Fig. 3D,E). These data are consistent with previous observations in these transgenic mice, in which there were no changes expression of the AMPA subtype of glutamate receptors in the adult mice (Lee et al., 2003) or in the visual cortex in young adult transgenic mice with GluR1 S831A and GluR1 S845A mutations (Goel et al., 2011). Although we did 
A

WT

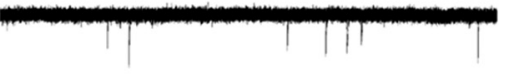

WT+PTZ

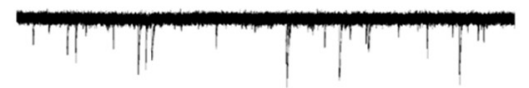

C1

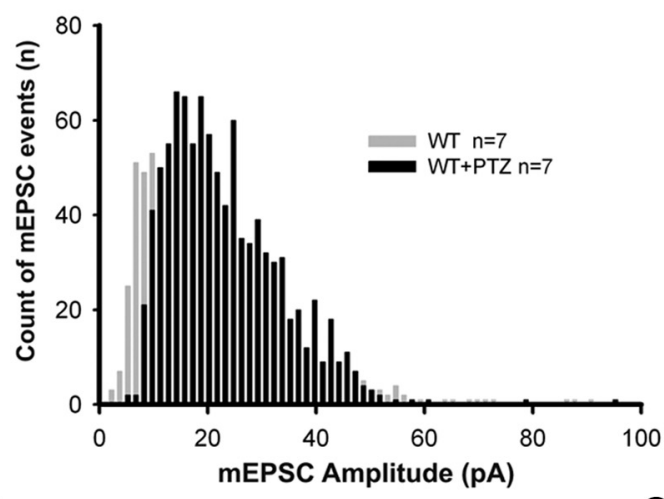

C3

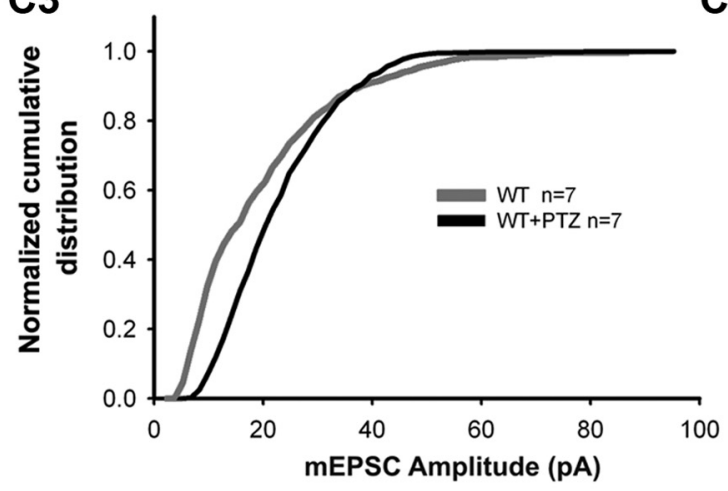

D1

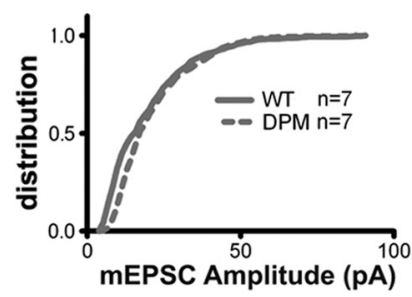

D2

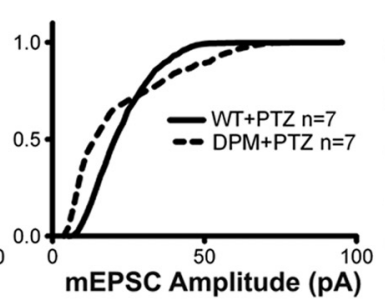

B

GluR1

DPM

\section{$20 \mathrm{pA} \mathrm{L}_{400 \mathrm{~ms}}$ GluR1}

\section{DPM+PTZ}

C2

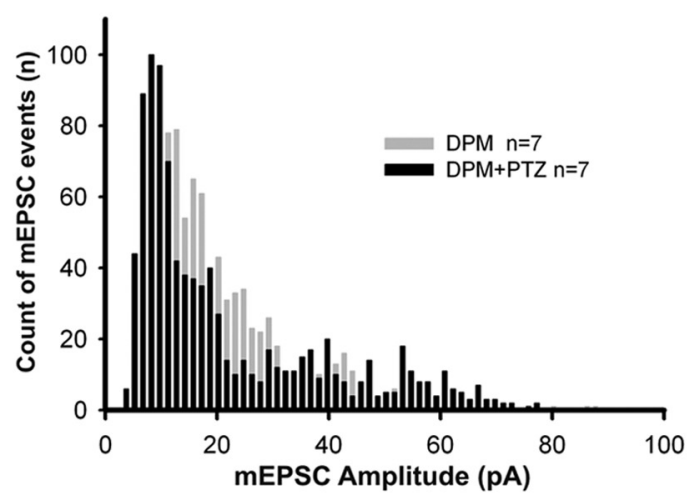

C4

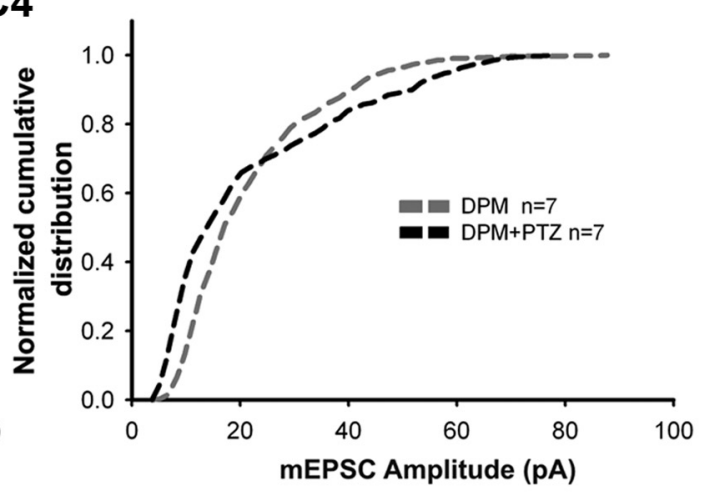

E1

E2

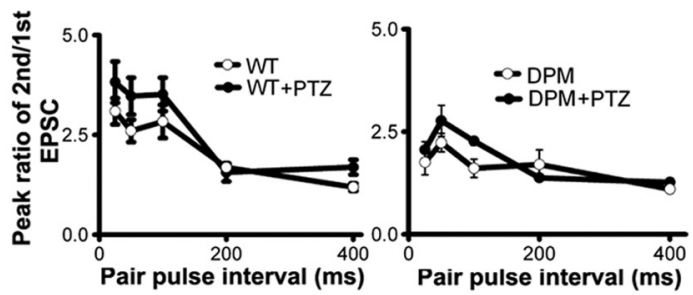

Figure 4. Attenuation of enhancement in hippocampal hyperexcitability subsequent to PTZ-induced seizures in GluR1 DPM mice. Representative recordings of AMPAR-mediated mEPSCs in CA1 neurons from WT hippocampal slices from mice with and without in vivo PTZ-induced seizures $(\boldsymbol{A})$ versus slices from GluR1 DPM mice with and without in vivo PTZ-induced seizures ( $\boldsymbol{B}$ ). $\boldsymbol{C}$, Amplitude histograms from WT mice with and without PTZ-induced seizures [WT control mEPSC event, total of $n=562,7$ cells (events per cell ranging from 50 and 140); WT post-PTZ seizure event, $n=971$, 7 cells (events per cell ranging between 29 and 261]; C2, GluR1 DPM mice with and without PTZ-induced seizures [GluR1 DPM control mEPSC event, $n=885,7$ cells (events per cell ranging between 54 and 219); GluR1 DPM post-PTZ seizure event, $n=945,7$ cells (events per cell ranging between 14 and 487)]. C3, C4, Cumulative probability plots for mEPSCs in WT mice with and without PTZ seizures (C3, $t$ test, $p=0.014)$ show a significant increase in mEPSC amplitude after PTZ seizures in WT mice. However, induction of PTZ seizures in the GluR1 DPM mice leads to significant decrease in mEPSC amplitude in GluR1 DPM mice compared with naive GluR1 DPM mice $(\mathbf{C}, t$ test, $p=0.002)$. D1, Replotting the WT and DPM cumulative distribution together in the same graph. D2, Replotting the WT + PTZ and DPM + PTZ cumulative distribution together in the same graph. E1, Comparison of paired-pulse EPSC recordings in CA1 pyramidal neurons in hippocampal slices from control pups and slices removed from pups at $24 \mathrm{~h}$ after PTZ-induced seizures. Cells were clamped at $-60 \mathrm{mV}$ and stimulated in Schaffer collaterals. The interval of pulses was $25,50,100,200$, and $400 \mathrm{~ms}$. E2, No significant effect on paired-pulse facilitation of evoked EPSCs was observed after PTZ seizures in the GluR1 DPM mice. 
not see any changes in overall AMPAR expression, alterations in the expression of other neurotransmitter receptors and signaling proteins involved in maintaining the excitation-inhibition balance after seizures may need to be evaluated in future studies.

\section{Enhanced excitability in hippocampal CA1 neurons observed} in WT mice after PTZ seizures is reversed in GluR1 DPM mice In the immature rat, seizure-induced phosphorylation of GluR1 S831 and S845 is associated with an increase in AMPARmediated EPSCs after seizures (Rakhade et al., 2008). We thus performed whole-cell patch-clamp recordings in CA1 neurons in ex vivo hippocampal slices removed from mice at baseline and after seizures in vivo. Similar to the lack of changes in baseline subunit expression observed above, we found no significant change in the baseline rise time for mEPSCs in WT mice $(2.33 \pm$ $0.21 \mathrm{~ms}, n=10)$ compared with recordings from GluR1 DPM mice $(2.12 \pm 0.14 \mathrm{~ms}, n=9, p=0.407)$. In addition, the baseline decay time for mEPSCs observed in slices from WT mice (8.56 \pm $0.88 \mathrm{~ms}, n=10$ ) was not significantly different from GluR1 DPM mice ( $7.01 \pm 0.98 \mathrm{~ms}, n=10, p=0.256)$. There was no significant difference in baseline mEPSC frequency between WT neurons (amplitude, $-14.79 \pm 1.45 \mathrm{pA}, n=12$; frequency, $0.175 \pm 0.04 \mathrm{~Hz}, n=12$ ) and GluR1 DPM neurons (amplitude, $-18.54 \pm 1.18 \mathrm{pA}, n=14$ cells, $p=0.058$; frequency, $0.16 \pm$ $0.04, n=14, p=0.75$ ) (Fig. 4D1), although this does represent a trend observed toward increased amplitude of AMPARmediated mEPSCs in the immature (P8) GluR1 DPM mice. Consistent with the lack of change in GluR2 expression by immunoblot, there was no significant change in the inward rectification ratios (evoked EPSC amplitude ratio at -60 to $40 \mathrm{mV}$ ) between the WT and GluR1 DPM mice (WT, $1.96 \pm 0.38, n=7$ vs DPM, $2.17 \pm 0.20, n=6, t$ test, $p=0.651)$. Collectively, these data do not reveal statistically significant alterations in baseline rise time, decay time, amplitude, and frequency of AMPARmediated synaptic currents in the GluR1 DPM mice at this age. Previous results have similarly shown a lack of change in basal synaptic transmission in the adult GluR1 DPM mice (Lee et al., 2003). However, similar to our data showing a trend to increased mEPSC amplitude in the DPM mice, recent studies in layer $2 / 3$ visual cortex at P21-P23 of GluR1 S831A and GluR1 S845A mutants show an increase in the basal mEPSC amplitude in AMPARmediated currents (Goel et al., 2011).

We next studied the ex vivo slices from mice after induction of PTZ seizures for changes in AMPAR-mediated currents in hippocampal CA1 cells to identify alterations in the excitability of the slices obtained from mice experiencing neonatal seizures (Fig. $4 A, B)$. In WT mice, recordings in CA1 neurons from slices removed $24 \mathrm{~h}$ after seizures from WT mice showed significantly larger-amplitude mEPSCs (amplitude, $-20.29 \pm 1.39 \mathrm{pA}, n=7$, $p=0.014$; frequency, $0.31 \pm 0.10 \mathrm{~Hz}, n=7, p=0.35$ ) compared with those from slices from naive control pups (amplitude, $-14.79 \pm 1.45 \mathrm{pA}, n=12$ cells; frequency, $0.175 \pm 0.04 \mathrm{~Hz}, n=$ 12) (Fig. 4C1,C3). The increased amplitude of mEPSCs at $24 \mathrm{~h}$ after neonatal seizures in the WT mice suggests an increase in the hippocampal hyperexcitability in this subacute time point, consistent with our previous results in the rat (Rakhade et al., 2008; Zhou et al., 2011). In contrast to recordings from WT mice, recordings from slices from DPM mice removed at $24 \mathrm{~h}$ after seizures showed a decrease in mEPSCs amplitude $(-12.93 \pm 1.07$ $\mathrm{pA}, n=8, p=0.002)$ and frequency $(0.17 \pm 0.05 \mathrm{~Hz}, n=8)$ compared with GluR1 DPM naive controls (amplitude, $-18.54 \pm 1.18 \mathrm{pA}, n=14$ cells, $p=0.005$; frequency, $0.16 \pm$ $0.041, n=14, p=0.34$ ) (Fig. 4C2,C4). The data suggest that, although HS induces an enhancement of AMPAR function in the WT mice, similar to the rat (Rakhade et al., 2008), these seizures result in a decrease in AMPAR function in GluR DPM mice. One possibility that we investigated was whether other GluR subunits were differentially modified, most notably the GluR2 subunit because it mediates $\mathrm{Ca}^{2+}$ permeability. Like the rat model, we observed enhanced phosphorylation of GluR2 S880 in the WT mice $(132 \pm 14 \%$ at $1 \mathrm{~h}, n=7, p<0.05)$ after PTZ seizures when compared with naive WT mice. Similarly, GluR1 DPM mice experiencing neonatal seizures also showed an enhancement $(187 \pm 19 \%, n=6$ at $1 \mathrm{~h}$ and $167 \pm 9 \%, n=6$ at $3 \mathrm{~h}$ after PTZ seizures, $p<0.05)$ compared with naive GluR1 DPM mice $(100 \pm 14 \%, n=6)$. In addition, the increase in GluR2 S880 phosphorylation was greater in GluR1 DPM mice (187 $\pm 19 \%$, $n=6, p<0.05)$ than that observed in WT $(132 \pm 14 \%, n=7)$. Given that phosphorylation of this site results in removal of GluR2-subunit containing receptors and increased $\mathrm{Ca}^{2+}$ permeability, other signaling pathways and/or homeostatic mechanisms may be accessed to a greater degree and may underlie the paradoxical decrease in mEPSC amplitude observed in recordings in slices from GluR1 DPM mice and merit future studies. Finally, no significant differences were observed in the pairedpulse facilitation in slices from WT mice after PTZ seizures compared with littermate controls, suggesting that the increase in excitability was most likely mediated by alterations in the postsynaptic component of potentiation (Fig. 4E1,E2). Similarly, no significant differences were observed in the inward rectification ratios in slices from GluR1 DPM mice experiencing PTZ seizures $(1.75 \pm 0.12, n=7)$ compared with GluR1 DPM mice not experiencing seizures $(2.17 \pm 0.2, n=6)$.

In summary, although WT mice show mEPSC potentiation similar to WT rat (Rakhade et al., 2008), this enhancement is not observed in the GluR1 DPM mice, which actually exhibit a decrease in mEPSC amplitude after seizures. These data suggest an important role for seizure-mediated S831 and S845 phosphorylation in the acute response to seizures.

\section{PTZ-induced seizures in WT mice increase expression of PSD-95}

In addition to enhanced mEPSCs, another consequence of phosphorylation of GluR1 is its trafficking into the synaptic membrane (Song and Huganir, 2002; Rakhade et al., 2008; Zhou et al., 2011). Synaptic potentiation has been associated with an increase the expression of the scaffolding protein PSD-95 and with enhanced AMPAR-mediated current amplitudes (Li et al., 1999; Stein et al., 2003; Ehrlich and Malinow, 2004). Turnover of PSD-95 protein that has been described previously in experiencedependent plasticity (El-Husseini Ael et al., 2002). There were no differences in the expression of PSD-95 in P7 GluR1 DPM mice $(83 \pm 7 \%, n=5, p=0.46)$ at baseline compared with agematched WT controls (100 $\pm 17 \%, n=5$ ) (Fig. 5A). In P7 WT mice, hippocampal PSD-95 expression was significantly increased as early as $1 \mathrm{~h}$ after PTZ-induced neonatal seizures and was maximal $48 \mathrm{~h}$ after PTZ seizures $(320 \%, n=6, p<0.05)$ compared with naive littermate controls (Fig. $5 A, B$ ). In contrast, this increase in PSD-95 expression was not observed in the littermate GluR1 DPM mice at 1 or $48 \mathrm{~h}$ after seizures $(140 \pm 27 \%, n=$ $7, p>0.05$ ) (Fig. $5 B, C$ ). In summary, PSD-95 is significantly increased transiently after early life seizures in WT but not GluR1 DPM mice, supporting a role for GluR1 S831 and S845 phosphorylation in post-seizure modifications at excitatory synapses. 


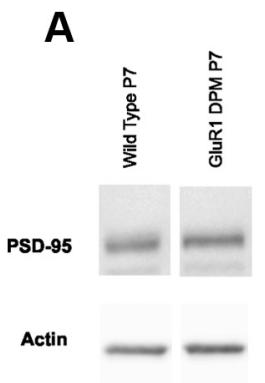

B

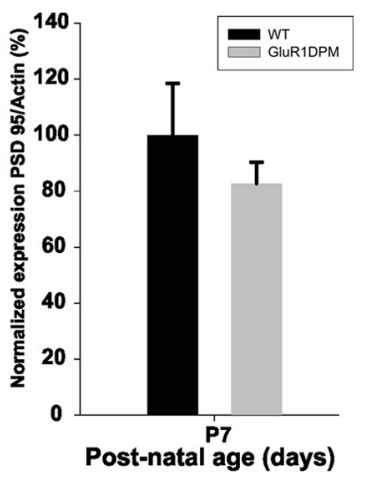

1 hour 12 hour 24 hour 48 hour

PSD-95

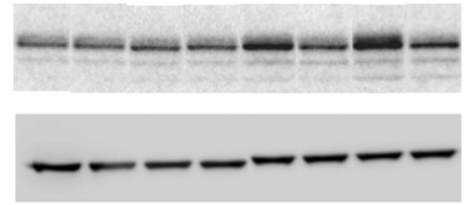

C

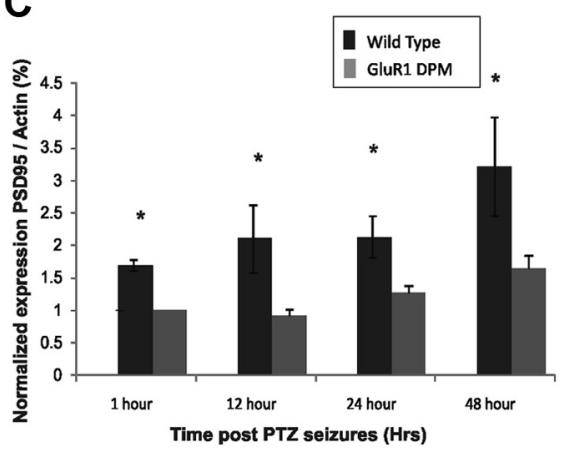

Figure 5. Increased expression of PSD-95 after PTZ-induced seizures in WT mice and attenuation of increase observed in GluR1 DPM mice. $\boldsymbol{A}$, Representative blots show PSD-95 expression in GluR1 DPM and WT mice at P7. $A$, The baseline expression of PSD-95 in GluR1 DPM mice at $P 7$ is not significantly different $(83 \pm 7 \%, n=5, p=0.46)$ compared with age-matched WT controls $(100 \pm 17 \%, n=5) . \boldsymbol{B}$, Representative blots show PSD-95 expression is increased in WT mice after PTZ neonatal seizures, the increase is attenuated in GluR1DPM mice. C, Earliest increase in PSD-95 expression is observed at $1 \mathrm{~h}$ after seizures and extends up to $48 \mathrm{~h}$ after seizures. The maximal increase in PSD-95 expression after PTZ seizures at P7 was observed $48 \mathrm{~h}$ after PTZ seizures $(320 \%, n=6, p<0.05)$ compared with Glur1 DPM mice not experiencing seizures $(100 \%, n=6)$. The increase in PSD-95 expression at $48 \mathrm{~h}$ after PTZ seizure induction as normalized to naive WT mice was $228 \%(n=6, p<0.05)$ (bar graph not shown). This increase in PSD-95 expression after neonatal seizures is attenuated in the GluR1 DPM mice (140\%, $n=$ $7, p>0.4$ ) compared with littermates not experiencing neonatal seizures (normalized to $100 \%, n=7) .{ }^{*} p<0.05$

Global hypoxia induces seizures in immature WT mice and results in increased phosphorylation of GluR1 S831 and GluR1 S845

A more subtle but clinically relevant seizure model is that of hypoxia-induced seizures, which has been well established in immature rats (Sanchez et al., 2005b; Silverstein and Jensen, 2007; Rakhade and Jensen, 2009). Exposure to graded global hypoxia for $40 \mathrm{~min}$ in P7-P9 mice leads to development of behavioral seizures characterized by myoclonic jerks, head shaking, pawing, and eventual progression to loss of posture. The highest incidence of seizures was seen at P9, with seizures in $85 \%$ of mice exposed to hypoxia (56 of 66 animals monitored after graded hypoxia showed the presence of behavioral seizures). Thus, we chose P9 for HS induction in this study. Using this model in WT
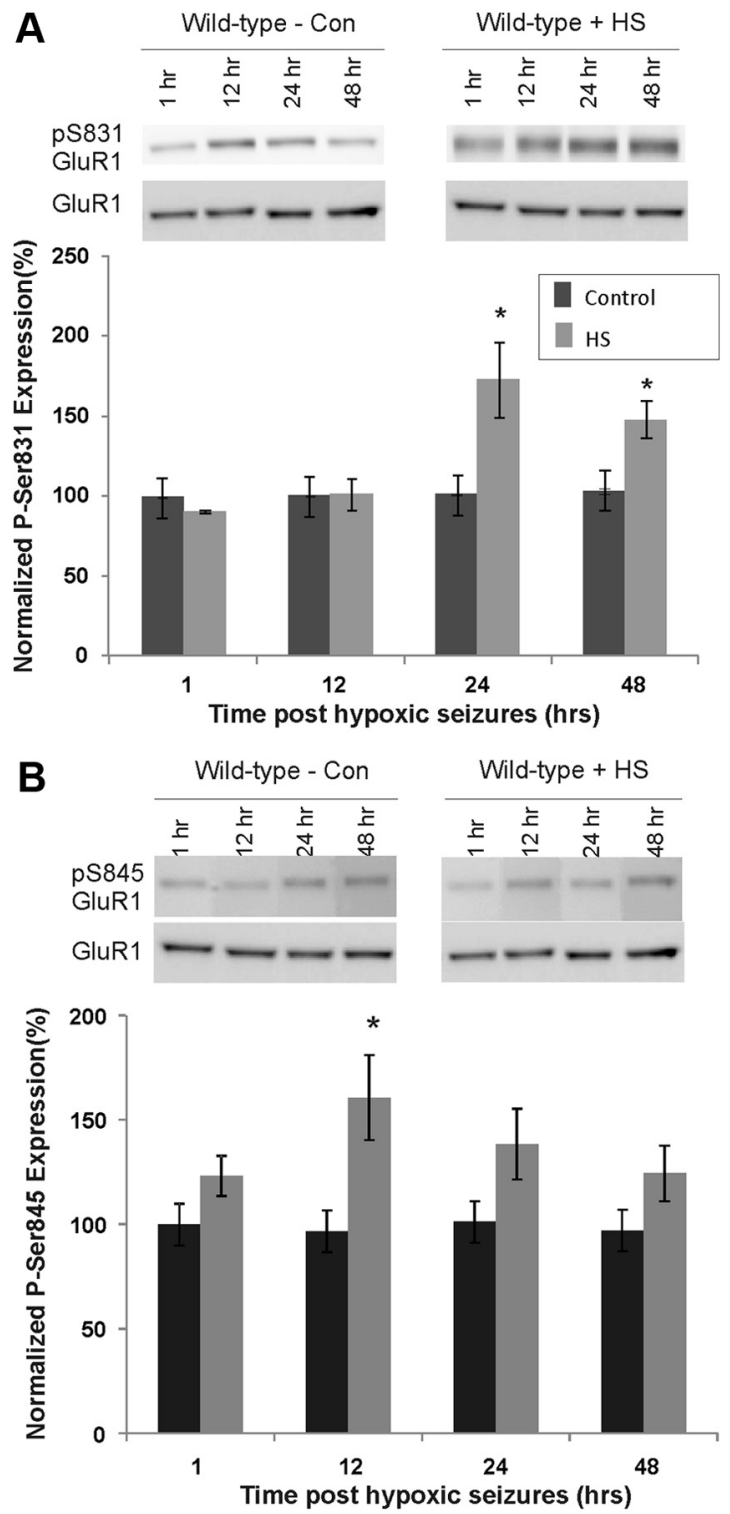

Figure 6. Increase in phosphorylation of GluR1 receptor after HS at P9, associated with increased hippocampal excitability. Immunoblots showing significant increase in phosphorylation of GluR1 S831 (A) and GluR1 S845 (B) at $24 \mathrm{~h}$ in WT mice after hypoxia-induced seizures at P9. Densitometry analysis and relative quantitation of phosphorylation of GluR1 subunit revealed the maximal increase at $24 \mathrm{~h}$ after HS for GluR1 $5831(182 \pm 27 \%, n=6, p<0.05)$ and maximal increase at $12 \mathrm{~h}$ after HS for GluR1 S845 (158 $\pm 19 \%, n=9, p<0.05)$ compared with non-seizing controls. ${ }^{*} p<0.05$.

mice, HS caused a phosphorylation of GluR1 S831 in cortex that was maximal $24 \mathrm{~h}$ for GluR1 S831 $(182 \pm 27 \%, n=6, p<0.05)$ compared with normoxic controls $(100 \pm 17 \%, n=6)$ (Fig. $6 A$ ). Similarly, an increase in GluR1 S845 phosphorylation (158 \pm $21 \%, n=9, p<0.05)$ was observed $12 \mathrm{~h}$ after the HS in cortex (Fig. 6B). These data demonstrate that, similar to the rat, HS during early development can result in increased phosphorylation of GluR1 subunit sites.

\section{GluR1 DPM mice show attenuated acute and long-term} effects after hypoxia-induced neonatal seizures

We next assessed whether there were differences in acute susceptibility to HS in GluR1 DPM and WT mice. Compared with WT mice, seizure incidence was lower in the GluR1 DPM mice (18 of 32 mice or $56 \%$ exhibited behavioral seizures compared with 
A

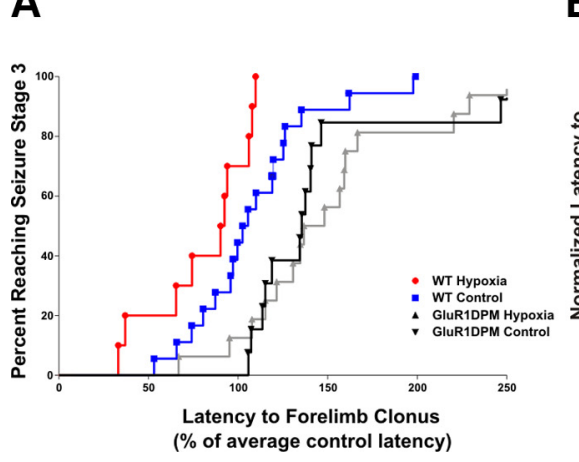

B

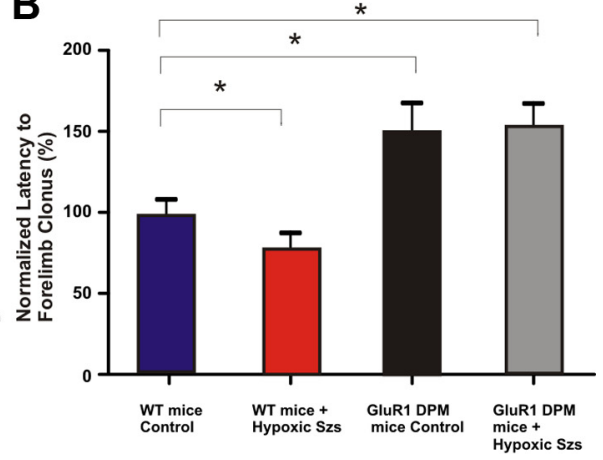

Figure 7. GluR1 DPM mice exposed to neonatal seizures fail to show an increase in susceptibility to later life seizures. $A$, GluR1 DPM mice and WT littermate controls were exposed to hypoxia-induced neonatal seizures at P9; the susceptibility to later life KA-induced seizures was studied at $P 40$. Onset of behavioral seizures and the percentage of animals experiencing seizures after KA injection (35 mg/kg, i.p.) in WT and GluR1 DPM mice that have been exposed to HS at P9 compared with control littermates. Progressive analysis of percentage of animals reaching stage 3 seizures compared with latency to onset of seizures shows a significant difference in the WT animals exposed to HS compared with normoxic controls. $\boldsymbol{B}$, Latency time for onset of tonic-clonic seizures was significantly faster in WT mice exposed to HS at P9 (68 $\pm 12 \%, n=14, p<0.05)$ compared with normoxic WT mice $(100 \pm 11 \%, n=16)$. Latency time was not significantly different in the GluR1 DPM $(-/-)$ mice experiencing neonatal seizures $(154 \pm 21 \%, n=12)$ compared with those not experiencing neonatal seizures $(152 \pm 19 \%, n=12, p=0.4) .{ }^{*} p<0.05$.

$85 \%$ of WT mice, $\chi^{2}$ test, $\left.p<0.05\right)$. Because early life hypoxiainduced seizures increase later life seizure susceptibility and spontaneous seizures in the rat model (Koh and Jensen, 2001; Rakhade et al., 2011), we similarly compared later seizure susceptibility threshold to KA-induced seizures (35 mg/kg, i.p.) in WT versus GluR1 DPM mice exposed to hypoxia at P9 versus naive littermates. WT mice with previous hypoxia-induced seizures had a significantly decreased latency to developing KA-induced forelimb clonus (Racine stage 3 seizures) ( $68 \pm 12 \%$ of control, $n=14, p<0.05)$ compared with normoxic littermate controls $(100 \pm 11 \%, n=16)$ (Fig. 7). In contrast, in GluR1 DPM mice, early life HS did not result in any difference in later life seizure susceptibility as measured by latency to first forelimb clonus $(154 \pm 21 \%, n=12)$ compared with normoxic GluR1 DPM littermate mice $(152 \pm 19 \%, n=12, p=0.4)$ (Fig. 7). These data support the hypothesis that seizure-induced phosphorylation of S831 and S845 critically contributes to later life network hyperexcitability and seizure susceptibility, suggesting a role in epileptogenesis.

Increased phosphorylation of GluR1 observed in postmortem human brain tissue from cases of neonatal seizures

Because we observed increased phosphorylation of the GluR1 receptor in multiple models of neonatal seizures, we examined whether there was evidence for phosphorylation at the GluR S831 or S845 site in human postmortem tissue from cases of neonatal seizures. Western blot analysis of GluR1 receptor subunit expression and its phosphorylation was performed using postmortem hippocampal tissue obtained from infants that had been diagnosed with neonatal seizures secondary to hypoxic encephalopathy $(n=3)$ (Table 1$)$ and compared with age-matched controls (control tissue obtained from infants $<6$ months age at death). Hippocampal samples from neonates with confirmed seizures showed increased phosphorylation of the GluR1 S831 (296 \pm $83 \%, n=3, p<0.05)$ compared with brain tissue from autopsy controls $(100 \pm 19 \%, p<0.05)$ and S845 receptor subunit $(232 \pm 72 \%, n=3, p<0.05)$ compared with brain tissue from autopsy controls $(100 \pm 16 \%, p<0.05)$ (Fig. 8$)$. These results show that phosphorylation of GluR1 S831 and S845 can be measured in human postmortem brain tissue and support the experimental animal data that this posttranslational modification may be a therapeutic target in human neonatal seizures.

\section{Discussion}

The present study is the first direct evidence to suggest a critical role for posttranslational modification of GluR1 S831 and S845 in the genesis of seizure-induced network excitability and that this may represent a potential therapeutic target in human brain tissue. Early life seizures in WT C57BL/6N mice pups lead to increased phosphorylation of the GluR1 subunit at S831 and S845 and commensurate increases in AMPAR-mediated $\mathrm{mEP}$ SCs in the hippocampal CA1 neurons. Furthermore, seizure-induced phosphorylation of GluR1 S831 and S845 was associated with increases in the synaptic scaffolding protein PSD-95. GluR1 DPM mice lacking the ability to phosphorylate S831 and S845 are less susceptible to PTZ and hypoxia-induced seizures and lacked the seizure-induced AMPAR potentiation, PSD-95 overexpression, as well as an attenuated long-term hyperexcitability that was observed in WT mice. These data implicate GluR1 phosphorylation as an important step upstream of mechanisms involved in initiation and maintenance of seizure-induced network hyperexcitability. Importantly, there was also evidence of increased phosphorylation of these subunits in human postmortem brain tissue from cases of neonatal seizures compared with control cases.

\section{Neonatal seizures lead to alterations in seizure susceptibility in $\mathrm{C} 57 \mathrm{BL} / 6 \mathrm{~N}$ mice}

Infants experiencing neonatal seizures have a significantly higher incidence of development of epilepsy, autism, and other cognitive and neurobehavioral disabilities. The pathological processes underlying these changes are likely to be multifactorial, but the imbalance between excitation and inhibition in the neuronal circuits plays a critical role in epileptogenesis (McNamara et al., 2006; Rakhade and Jensen, 2009). Given the relative preponderance of GluR2-lacking, $\mathrm{Ca}^{2+}$-permeable AMPARs during this window, the effects of any change in synaptic plasticity signaling cascades are likely to be accentuated. Here we report a new model and methods for inducing hypoxia-induced seizures in C57BL/6 mice, because previous studies were performed in rats that demonstrated functional enhancement of AMPARs associated with increased phosphorylation of GluR1 S831 and S845 within $24 \mathrm{~h}$ after HS (Rakhade et al., 2008; Zhou et al., 2011). Unambiguous proof of a role for these novel posttranslational modifications in epilepsy required reestablishing this model in a transgenic mouse lacking the ability to phosphorylate these sites (Lee et al., 2003). In P7-P9 WT mice, seizures induced by either PTZ or global hypoxia increased phosphorylation of GluR1 S831 and S845. The increase in GluR1 phosphorylation was observed as early as $1 \mathrm{~h}$ after the PTZ seizures, providing a mechanism for early alterations in the transition of the normal hippocampal circuits into hyperexcitable circuits.

Enhanced excitability and synaptic potentiation mediated by increased synaptic AMPARs and occluded LTP have been observed previously in the hippocampal CA1 neurons immediately 
A
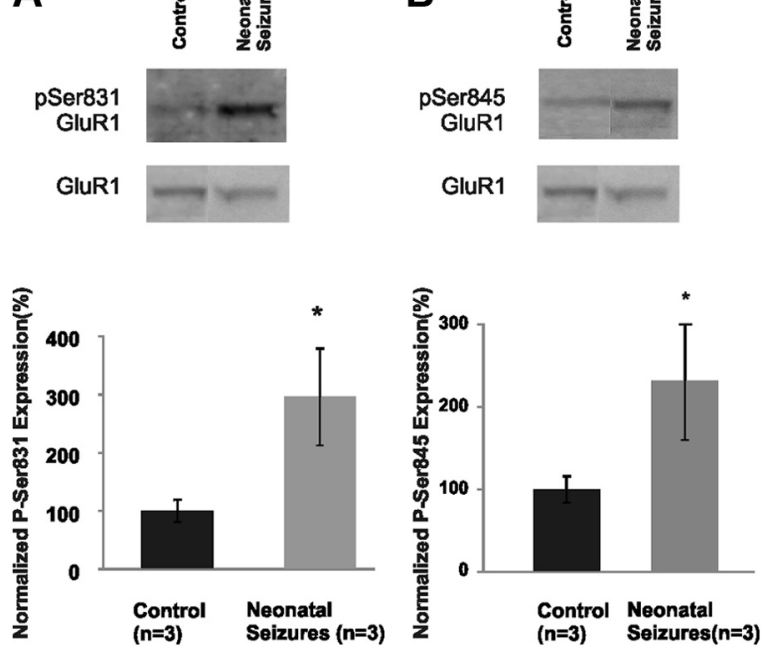

Figure 8. Increase in phosphorylation of GluR1 receptor in hippocampi from early childhood cases with neonatal seizures. $\boldsymbol{A}$, Representative Western blots depicting increased phosphorylation of GluR1 S831 and GluR1 S845 in hippocampal tissue obtained from subjects who had experienced hypoxic encephalopathy before death at term; comparison were made with hippocampal tissue obtained from age-matched autopsy controls. Phosphorylation of GluR1 S831 was increased in hippocampal tissue (average of $296 \pm 83 \%, n=3, p<0.05$ ) compared with age-matched controls. $\boldsymbol{B}$, Similarly, increase in phosphorylation of GluR1 $\mathbf{S 8 4 5}$ was also detected (average of $232 \pm 72 \%, n=3, p<0.05$ ) compared with brain tissue from autopsy controls. ${ }^{*} p<0.05$.

after early life seizures in the rat model of hypoxia-induced seizures (Jensen et al., 1998; Rakhade et al., 2008; Zhou et al., 2011). These alterations in synaptic potentiation and hippocampal excitability are not observed after induction of hypoxia alone; seizures are required for initiating these changes (Zhou et al., 2011). In rats, neonatal seizures can lead to later life alterations in plasticity at glutamatergic synapses in the hippocampus (Cornejo et al., 2007), accompanied by alterations in synaptic neurotransmitters, silent synapses and deficits in spatial memory, and impaired LTP and learning (Mikati et al., 2005; Zhou et al., 2011). In addition, this study establishes a model of hypoxia-induced neonatal seizures in WT mice that exhibit similar consequences in posttranslational GluR1 modifications and seizure susceptibility as the rat model (Rakhade et al., 2008). Chemically induced seizures in WT mice also lead to these alterations in hippocampal synaptic excitability and susceptibility to later life seizures.

\section{GluR1 phosphorylation contributes to seizure-induced increases in AMPAR-mediated synaptic transmission and later life in vivo seizure susceptibility}

GluR1 phosphorylation has been shown to result in changes in AMPAR kinetics and amplitude, synaptic trafficking, and insertion of AMPARs in the synaptic membrane (Shepherd and Huganir, 2007) and plays a critical role in mediating LTP and long-term depression after appropriate stimuli (Mammen et al., 1997; Derkach et al., 1999, 2007). GluR1 phosphorylation at S845 leads to an increase in the reinsertion of GluR1 subunits at the PSD and phosphorylation at S831 leads to an increase in the conductance of AMPARs during the induction of LTP. The first 2 postnatal weeks in rodents is a critical period in development, with multiple changes that affect the balance of excitation and inhibition in the brain (Rakhade and Jensen, 2009). Here, we have observed that acute seizures increase AMPAR-mediated mEPSC amplitude in WT mice, similar to the results described previously in the rat model of neonatal seizures (Rakhade et al.,
2008). However, neonatal seizures in the GluR1 DPM mice result in a decrease in AMPAR-mediated mEPSC amplitude, this paradoxical effect suggesting that the phosphorylation of GluR1 receptors plays an important role for mediating the excitability observed $24 \mathrm{~h}$ after the initial seizures. The decrease in MEPSC amplitude observed after PTZ-induced seizures in the GluR1 DPM mice may involve interactions between phosphorylation events that promote homeostatic events, such as trafficking and stabilization of the AMPARs via internalization and lysosomal degradation of these receptors (Shepherd and Huganir, 2007; Heine et al., 2008; He et al., 2009). We hypothesize that the synaptic changes observed after neonatal seizures may be attributable to complex interactions between the AMPAR phosphorylation and trafficking, in combination with homeostatic mechanisms involved in maintaining the excitation-inhibition imbalance. Indeed, previous studies have suggested that GluR1 S845 phosphorylation plays an important role in stabilizing $\mathrm{Ca}^{2+}$-permeable AMPARs and preventing their lysosomal degradation (Ehlers, 2000; Goel and Lee, 2007; Man et al., 2007; He et al., 2009; Goel et al., 2011). The lack of GluR1 8845 phosphorylation in the GluR1 DPM mice may significantly enhance the lysosomal degradation of the internalized GluR1-containing receptors and may affect the perisynaptic AMPARs that are available for "ready insertion" in response to neuronal activity (He et al., 2009). Furthermore, enhanced GluR2 phosphorylation at S880 observed after neonatal seizure may contribute to receptor internalization and expression of $\mathrm{Ca}^{2+}$-permeable AMPARs at the synaptic surface (Rakhade et al., 2008).

Recent studies using single molecule tracking to detect the movement of AMPARs have shown that GluR1-containing AMPARs freely diffuse in and out of the synapse within the PSD (Heine et al., 2008; Petrini et al., 2009), and anchoring them at the synapse may require PDZ domain interactions. Future studies may reveal the mechanisms involved in mediating this effect on AMPAR-mediated mEPSCs after PTZ-induced seizures, and compensatory changes in the excitation-inhibition imbalance may provide information regarding the specific mechanism involved in the paradoxical change observed. Animal models of seizures induced by use of chemoconvulsants in early life have shown multifactorial changes, including alterations in the GABA receptors and AMPARs (Zhang et al., 2004; Silva et al., 2005; Friedman et al., 2007).

GluR1 DPM mice retain the ability to exhibit seizures in the presence of PTZ but display an increased latency to the onset of these behavioral seizures. There does not appear to be significant changes in baseline expression of AMPAR GluR1 or GluR2 subunits or in baseline mEPSCs in hippocampal neurons studied in the GluR1 DPM and WT mice. Furthermore, we did not observe a difference in the rise time, decay time, and frequency of AMPAR-mediated mEPSCs between the naive WT and GluR1 DPM mice at P8. Consistently, previous reports comparing GluR1 DPM mice with WT did not show any significant abnormalities in anatomical structure, receptor subunit distribution, baseline synaptic transmission, and transport of receptors to the synaptic surface (Lee et al., 2003).

Phosphorylation of the GluR1 subunit has been reported to be critical for multiple synaptic potentiation events, including trafficking of GluR1-containing receptors, stabilization at the synaptic surface, maintenance of LTP, as well as lysosomal internalization and degradation of $\mathrm{Ca}^{2+}$-permeable AMPARs (Shepherd and Huganir, 2007; Heine et al., 2008). Previous reports have suggested that increased GluR2 S880 phosphorylation may result in the enhanced persistence of $\mathrm{Ca}^{2+}$-permeable AMPARs after 
neonatal seizures (Rakhade et al., 2008) and status epilepticus (Rajasekaran et al., 2012). The increased phosphorylation of GluR2 S880 after chemoconvulsant-induced seizures can further influence the AMPAR-mediated synaptic currents and synaptic excitability after neonatal seizures.

Here, we propose that the differences observed in synaptic potentiation in GluR1 DPM mice after the initial neonatal seizures are important in initiating, and also perhaps the maintenance, of the susceptibility to seizures observed in later life. After induction of seizures at P7-P9, seizure susceptibility to KAprovoked seizures in adulthood was increased in WT mice. In contrast, later seizure susceptibility was unchanged in naive GluR1 DPM mice compared with those exposed to early life seizures. Susceptibility to KA-induced seizures in later life represents a surrogate for long-term susceptibility to developing epileptic seizures and has been used previously in rodent models (Huang et al., 1999; Koh and Jensen, 2001; Koh et al., 2004). The lack of change in seizure susceptibility in GluR1 DPM mice suggests that these mice may be less prone to development of later life epilepsy. Future studies evaluating the development of spontaneous recurrent seizures after induction of neonatal seizures in the GluR1 DPM and WT mice may provide significant evidence regarding the role of these posttranslational modifications in epileptogenesis.

Stabilization of GluR1 receptors during the maintenance of LTP is thought to be dependent on its attachment to the PSD proteins (Lisman and Raghavachari, 2006). In models of synaptic potentiation, $\mathrm{Ca}^{2+}$ influx after enhanced activity leads to activation of kinases, such as CaMKII and PKA, which in turn bind to the intracellular tails of the receptor at the PSD (Yoshimura et al., 2000; Lisman et al., 2002). CaMKII and other associated proteins have been proposed to act as slot proteins for AMPAR insertion (Lisman and Zhabotinsky, 2001), and previous reports have shown enhanced activity of CaMKII in the postsynaptic membrane after neonatal seizures in animal models (Cornejo et al., 2007; Rakhade et al., 2008). Recent data has led to the recognition of distinct process involved in exocytosis of the intracellular AMPARs to extra/perisynaptic sites, lateral diffusion to synaptic sites, and retention at synapses via scaffolding proteins (Petrini et al., 2009; Opazo and Choquet, 2011). Increased phosphorylation of the GluR1 receptor after neonatal seizures may affect some of these processes and alter the balance between excitation and inhibition, promoting development of seizures. PSD-95 overexpression has been found to drive the recruitment of AMPARs to synaptic sites (Stein et al., 2003; Ehrlich and Malinow, 2004). The enhanced phosphorylation of GluR1 receptors and the increased expression of PSD-95 after early life PTZ-induced seizures suggest that mechanisms similar to those involved in synaptic potentiation may be involved in maintaining hyperexcitability and seizure susceptibility. Constant interplay between these synaptic mechanisms leading to potentiation of neuronal networks and homeostatic mechanisms involved in maintaining the excitation-inhibition balance may be involved in either promoting epileptogenesis or preventing the susceptibility to later life seizures, respectively.

\section{Increased GluR1 phosphorylation is observed in postmortem human tissue from neonatal seizures cases}

A novel finding in this study was that the phosphorylation of GluR1 S831 and S845 was increased in the postmortem samples of hippocampi of three patients who had experienced neonatal seizures and had succumbed to related complications during infancy compared with three age-matched autopsy control cases.
The increase in GluR1 phosphorylation in the human subjects who had experienced neonatal seizures suggests that this phenomenon observed in the animal models recapitulates the alterations that are relevant to the human disease condition. Children suffering from neonatal seizures have a significantly increased risk for developing epilepsy and cognitive disabilities in later life; in fact, the lifetime incidence of these associated problems reflects a far greater disease burden than the neonatal seizures themselves (Mizrahi and Kellaway, 1998; Mizrahi, 1999; Ronen et al., 2007). The molecular mechanisms involved in the development of these long-term sequelae are incompletely understood despite intense investigation. The current study highlights the potential role of posttranslational modification of a critical neurotransmitter receptor in epileptogenesis; it may represent a potential target in at least a subset of the population experiencing neonatal seizures. This study provides a proof of concept for the therapeutic implications of these findings in the human disease process of epileptogenesis in the immature brain.

\section{References}

Barria A, Derkach V, Soderling T (1997) Identification of the $\mathrm{Ca}^{2+} /$ calmodulin-dependent protein kinase II regulatory phosphorylation site in the alpha-amino-3-hydroxyl-5-methyl- 4-isoxazole-propionate-type glutamate receptor. J Biol Chem 272:32727-32730. CrossRef Medline

Ben-Ari Y, Holmes GL (2006) Effects of seizures on developmental processes in the immature brain. Lancet Neurol 5:1055-1063. CrossRef Medline

Billa SK, Sinha N, Rudrabhatla SR, Morón JA (2009) Extinction of morphine-dependent conditioned behavior is associated with increased phosphorylation of the GluR1 subunit of AMPA receptors at hippocampal synapses. Eur J Neurosci 29:55-64. CrossRef Medline

Chen K, Baram TZ, Soltesz I (1999) Febrile seizures in the developing brain result in persistent modification of neuronal excitability in limbic circuits. Nat Med 5:888-894. CrossRef Medline

Cornejo BJ, Mesches MH, Coultrap S, Browning MD, Benke TA (2007) A single episode of neonatal seizures permanently alters glutamatergic synapses. Ann Neurol 61:411-426. CrossRef Medline

Derkach VA, Oh MC, Guire ES, Soderling TR (2007) Regulatory mechanisms of AMPA receptors in synaptic plasticity. Nat Rev Neurosci 8:101113. CrossRef Medline

Derkach V, Barria A, Soderling TR (1999) $\mathrm{Ca}^{2+} /$ calmodulin-kinase II enhances channel conductance of alpha-amino-3- hydroxy-5-methyl-4isoxazolepropionate type glutamate receptors. Proc Natl Acad Sci U S A 96:3269-3274. CrossRef Medline

Ehlers MD (2000) Reinsertion or degradation of AMPA receptors determined by activity-dependent endocytic sorting. Neuron 28:511-525. CrossRef Medline

Ehrlich I, Malinow R (2004) Postsynaptic density 95 controls AMPA receptor incorporation during long-term potentiation and experience-driven synaptic plasticity. J Neurosci 24:916-927. CrossRef Medline

El-Husseini Ael-D, Schnell E, Dakoji S, Sweeney N, Zhou Q, Prange O, Gauthier-Campbell C, Aguilera-Moreno A, Nicoll RA, Bredt DS (2002) Synaptic strength regulated by palmitate cycling on PSD-95. Cell 108: 849-863. CrossRef Medline

Friedman LK, Avallone JM, Magrys B (2007) Maturational effects of single and multiple early-life seizures on AMPA receptors in prepubescent hippocampus. Dev Neurosci 29:427-437. CrossRef Medline

Goel A, Lee HK (2007) Persistence of experience-induced homeostatic synaptic plasticity through adulthood in superficial layers of mouse visual cortex. J Neurosci 27:6692-6700. CrossRef Medline

Goel A, Xu LW, Snyder KP, Song L, Goenaga-Vazquez Y, Megill A, Takamiya K, Huganir RL, Lee HK (2011) Phosphorylation of AMPA receptors is required for sensory deprivation-induced homeostatic synaptic plasticity. PLoS One 6:e18264. CrossRef Medline

Hauser WA, Annegers JF, Kurland LT (1993) Incidence of epilepsy and unprovoked seizures in Rochester, Minnesota: 1935-1984. Epilepsia 34:453-468. CrossRef Medline

He K, Song L, Cummings LW, Goldman J, Huganir RL, Lee HK (2009) Stabilization of $\mathrm{Ca}^{2+}$-permeable AMPA receptors at perisynaptic sites by 
GluR1-S845 phosphorylation. Proc Natl Acad Sci U S A 106:2003320038. CrossRef Medline

Heine M, Groc L, Frischknecht R, Béique JC, Lounis B, Rumbaugh G, Huganir RL, Cognet L, Choquet D (2008) Surface mobility of postsynaptic AMPARs tunes synaptic transmission. Science 320:201-205. CrossRef Medline

Hu H, Real E, Takamiya K, Kang MG, Ledoux J, Huganir RL, Malinow R (2007) Emotion enhances learning via norepinephrine regulation of AMPA-receptor trafficking. Cell 131:160-173. CrossRef Medline

Huang L, Cilio MR, Silveira DC, McCabe BK, Sogawa Y, Stafstrom CE, Holmes GL (1999) Long-term effects of neonatal seizures: a behavioral, electrophysiological, and histological study. Brain Res Dev Brain Res 118: 99-107. CrossRef Medline

Jensen FE (2011) Epilepsy as a spectrum disorder: Implications from novel clinical and basic neuroscience. Epilepsia 52 [Suppl 1]:1-6.

Jensen FE, Wang C, Stafstrom CE, Liu Z, Geary C, Stevens MC (1998) Acute and chronic increases in excitability in rat hippocampal slices after perinatal hypoxia in vivo. J Neurophysiol 79:73-81. Medline

Kapus G, Székely JI, Durand J, Ruiz A, Tarnawa I (2000) AMPA receptor antagonists, GYKI 52466 and NBQX, do not block the induction of longterm potentiation at therapeutically relevant concentrations. Brain Res Bull 52:511-517. CrossRef Medline

Koh S, Jensen FE (2001) Topiramate blocks perinatal hypoxia-induced seizures in rat pups. Ann Neurol 50:366-372. CrossRef Medline

Koh S, Tibayan FD, Simpson JN, Jensen FE (2004) NBQX or topiramate treatment following perinatal hypoxia-induced seizures prevents later increases in seizure-induced neuronal injury. Epilepsia 45:569-575. CrossRef Medline

Kumar SS, Bacci A, Kharazia V, Huguenard JR (2002) A developmental switch of AMPA receptor subunits in neocortical pyramidal neurons. J Neurosci 22:3005-3015. Medline

Lee HK, Barbarosie M, Kameyama K, Bear MF, Huganir RL (2000) Regulation of distinct AMPA receptor phosphorylation sites during bidirectional synaptic plasticity. Nature 405:955-959. CrossRef Medline

Lee HK, Takamiya K, Han JS, Man H, Kim CH, Rumbaugh G, Yu S, Ding L, He C, Petralia RS, Wenthold RJ, Gallagher M, Huganir RL (2003) Phosphorylation of the AMPA receptor GluR1 subunit is required for synaptic plasticity and retention of spatial memory. Cell 112:631-643. CrossRef Medline

Li P, Kerchner GA, Sala C, Wei F, Huettner JE, Sheng M, Zhuo M (1999) AMPA receptor-PDZ interactions in facilitation of spinal sensory synapses. Nat Neurosci 2:972-977. CrossRef Medline

Lisman J, Raghavachari S (2006) A unified model of the presynaptic and postsynaptic changes during LTP at CA1 synapses. Sci STKE 2006:re11. CrossRef Medline

Lisman JE, Zhabotinsky AM (2001) A model of synaptic memory: a CaMKII/ PP1 switch that potentiates transmission by organizing an AMPA receptor anchoring assembly. Neuron 31:191-201. CrossRef Medline

Lisman J, Schulman H, Cline H (2002) The molecular basis of CaMKII function in synaptic and behavioural memory. Nat Rev Neurosci 3:175190. CrossRef Medline

Mammen AL, Kameyama K, Roche KW, Huganir RL (1997) Phosphorylation of the alpha-amino-3-hydroxy-5-methylisoxazole4-propionic acid receptor GluR1 subunit by calcium/calmodulin-dependent kinase II. J Biol Chem 272:32528-32533. CrossRef Medline

Man HY, Sekine-Aizawa Y, Huganir R (2007) Regulation of à-amino-3hydroxy-5-methyl-4-isoxazolepropionic acid receptor trafficking through PKA phosphorylation of the Glu receptor 1 subunit. Proc Natl Acad Sci U S A 104:3579-3584. CrossRef Medline

McNamara JO, Huang YZ, Leonard AS (2006) Molecular signaling mechanisms underlying epileptogenesis. Sci STKE 2006:re12. CrossRef Medline

Mikati MA, Zeinieh MP, Kurdi RM, Harb SA, El Hokayem JA, Daderian RH, Shamseddine A, Obeid M, Bitar FF, El Sabban M (2005) Long-term effects of acute and of chronic hypoxia on behavior and on hippocampal histology in the developing brain. Brain Res Dev Brain Res 157:98-102. CrossRef Medline

Mizrahi EM (1999) Acute and chronic effects of seizures in the developing brain: lessons from clinical experience. Epilepsia 40 [Suppl 1]:S42-S50.

Mizrahi EM, Kellaway P (1998) Diagnosis and management of neonatal seizures. Philadelphia: Lippincott-Raven.

Opazo P, Choquet D (2011) A three-step model for the synaptic recruitment of AMPA receptors. Mol Cell Neurosci 46:1-8. CrossRef Medline
Petrini EM, Lu J, Cognet L, Lounis B, Ehlers MD, Choquet D (2009) Endocytic trafficking and recycling maintain a pool of mobile surface AMPA receptors required for synaptic potentiation. Neuron 63:92-105. CrossRef Medline

Rajasekaran K, Todorovic M, Kapur J (2012) Calcium-permeable AMPA receptors are expressed in a rodent model of status epilepticus. Ann Neurol 72:91-102. CrossRef Medline

Rakhade SN, Jensen FE (2009) Epileptogenesis in the immature brain: emerging mechanisms. Nat Rev Neurol 5:380-391. CrossRef Medline

Rakhade SN, Zhou C, Aujla PK, Fishman R, Sucher NJ, Jensen FE (2008) Early alterations of AMPA receptors mediate synaptic potentiation induced by neonatal seizures. J Neurosci 28:7979-7990. CrossRef Medline

Rakhade SN, Klein PM, Huynh T, Hilario-Gomez C, Kosaras B, Rotenberg A, Jensen FE (2011) Development of later life spontaneous seizures in a rodent model of hypoxia-induced neonatal seizures. Epilepsia 52:753-765. CrossRef Medline

Ramzan IM, Levy G (1985) Kinetics of drug action in disease states. XV. Effect of pregnancy on the convulsive activity of pentylenetetrazol in rats. J Pharm Sci 74:1233-1235. CrossRef Medline

Ronen GM, Buckley D, Penney S, Streiner DL (2007) Long-term prognosis in children with neonatal seizures: a population-based study. Neurology 69:1816-1822. CrossRef Medline

Sanchez RM, Koh S, Rio C, Wang C, Lamperti ED, Sharma D, Corfas G, Jensen FE (2001) Decreased glutamate receptor 2 expression and enhanced epileptogenesis in immature rat hippocampus after perinatal hypoxia-induced seizures. J Neurosci 21:8154-8163. Medline

Sanchez RM, Dai W, Levada RE, Lippman JJ, Jensen FE (2005a) AMPA/ kainate receptor-mediated downregulation of GABAergic synaptic transmission by calcineurin after seizures in the developing rat brain. J Neurosci 25:3442-3451. CrossRef Medline

Sanchez RM, Jensen FE, Pitanken A, Schwartzkroin PA, Moshe SL (2005b) Modeling hypoxia-induced seizures and hypoxic encephalopathy in the neonatal period. In: Models of seizures and epilepsy. San Diego: Elsevier.

Shepherd JD, Huganir RL (2007) The cell biology of synaptic plasticity: AMPA receptor trafficking. Annu Rev Cell Dev Biol 23:613-643. CrossRef Medline

Silva AV, Regondi MC, Cipelletti B, Frassoni C, Cavalheiro EA, Spreafico R (2005) Neocortical and hippocampal changes after multiple pilocarpineinduced status epilepticus in rats. Epilepsia 46:636-642. CrossRef Medline

Silverstein FS, Jensen FE (2007) Neonatal seizures. Ann Neurol 62:112-120. CrossRef Medline

Sogawa Y, Monokoshi M, Silveira DC, Cha BH, Cilio MR, McCabe BK, Liu X, Hu Y, Holmes GL (2001) Timing of cognitive deficits following neonatal seizures: relationship to histological changes in the hippocampus. Brain Res Dev Brain Res 131:73-83. CrossRef Medline

Song I, Huganir RL (2002) Regulation of AMPA receptors during synaptic plasticity. Trends Neurosci 25:578-588. CrossRef Medline

Stein V, House DR, Bredt DS, Nicoll RA (2003) Postsynaptic density-95 mimics and occludes hippocampal long-term potentiation and enhances long-term depression. J Neurosci 23:5503-5506. Medline

Talos DM, Fishman RE, Park H, Folkerth RD, Follett PL, Volpe JJ, Jensen FE (2006) Developmental regulation of alpha-amino-3-hydroxy-5-methyl4-isoxazole-propionic acid receptor subunit expression in forebrain and relationship to regional susceptibility to hypoxic/ischemic injury. I. Rodent cerebral white matter and cortex. J Comp Neurol 497:42-60. CrossRef Medline

Talos DM, Sun H, Zhou X, Fitzgerald EC, Jackson MC, Klein PM, Lan VJ, Joseph A, Jensen FE (2012) The interaction between early life epilepsy and autistic-like behavioral consequences: a role for the mammalian target of rapamycin (mTOR) pathway. PLoS One 7:e35885. CrossRef Medline

Velisek L, Kubova H, Pohl M, Stankova L, Mares P, Schickerova R (1992) Pentylenetetrazol-induced seizures in rats: an ontogenetic study. Naunyn Schmiedebergs Arch Pharmacol 346:588-591. CrossRef Medline

Wenthold RJ, Yokotani N, Doi K, Wada K (1992) Immunochemical characterization of the non-NMDA glutamate receptor using subunit-specific antibodies. J Biol Chem 267:501-507. Medline

Wyllie DJ, Nicoll RA (1994) A role for protein kinases and phosphatases in the $\mathrm{Ca}^{2+}$-induced enhancement of hippocampal AMPA receptormediated synaptic responses. Neuron 13:635-643. CrossRef Medline

Yoshimura Y, Aoi C, Yamauchi T (2000) Investigation of protein substrates 
of $\mathrm{Ca}^{2+} /$ calmodulin-dependent protein kinase II translocated to the postsynaptic density. Brain Res Mol Brain Res 81:118-128. CrossRef Medline

Zhang G, Raol YH, Hsu FC, Coulter DA, Brooks-Kayal AR (2004) Effects of status epilepticus on hippocampal GABAA receptors are age-dependent. Neuroscience 125:299-303. CrossRef Medline
Zhou C, Lippman JJ, Sun H, Jensen FE (2011) Hypoxia-induced neonatal seizures diminish silent synapses and long-term potentiation in hippocampal CA1 neurons. J Neurosci 31:18211-18222. CrossRef Medline 